\title{
From Sustainability-as-usual to Sustainability Excellence in Local Bioenergy Business
}

\author{
Heli Kasurinen*"1, Ville Uusitalo $^{2}$, Sanni Väisänen ${ }^{3}$, Risto Soukka ${ }^{4}$, \\ Jouni Havukainen ${ }^{5}$ \\ ${ }^{1}$ Sustainability Science, Lappeenranta University of Technology, Skinnarilankatu 34, \\ 53850 Lappeenranta, Finland \\ e-mail: heli.kasurinen@lut.fi \\ ${ }^{2}$ Sustainability Science, Lappeenranta University of Technology, Skinnarilankatu 34, \\ 53850 Lappeenranta, Finland \\ e-mail: ville.uusitalo@lut.fi \\ ${ }^{3}$ Sustainability Science, Lappeenranta University of Technology, Skinnarilankatu 34, \\ 53850 Lappeenranta, Finland \\ e-mail: $\underline{\text { sanni.vaisanen@lut.fi }}$ \\ ${ }^{4}$ Sustainability Science, Lappeenranta University of Technology, Skinnarilankatu 34, \\ 53850 Lappeenranta, Finland \\ e-mail: risto.soukka@lut.fi \\ ${ }^{5}$ Sustainability Science, Lappeenranta University of Technology, Skinnarilankatu 34, \\ 53850 Lappeenranta, Finland \\ e-mail: jouni.havukainen@lut.fi
}

\begin{abstract}
Bioenergy business operators can significantly contribute to the sustainability of bioenergy systems. While research has addressed the maturity of corporate responsibility for sustainability, the maturity levels of bioenergy business have not been determined. The objectives of this research were to characterise the maturity levels of bioenergy corporate responsibility for sustainability and outline an approach by which companies can operate at the most mature sustainability excellence level. Literature, three workshops attended by bioenergy experts and a case study on biobutanol production in Brazil were used to develop the maturity model and approach. The results characterise the profitability, acceptability, and sustainability orientation maturity levels through sustainability questions and methods, and list the components of a systemic, holistic approach. Although the shift of business mindset from sustainability-as-usual to sustainability excellence is challenging, a systemic approach is necessary to broadly identify sustainability questions and a multitude of methods by which they can be answered.
\end{abstract}

\section{KEYWORDS}

Sustainability, Bioenergy, Biofuel, Biobutanol, System analysis, Life cycle.

\footnotetext{
* Corresponding author
} 


\section{INTRODUCTION}

In $2013,10 \%$ of the global total primary energy supply, 13,541 Mtoe, was derived from biofuels and waste [1]. Bioenergy business operators play a fundamental role in enhancing the extent to which sustainably produced biofuels are in use. Effort has been invested in the form of legislative steering, standardisation and scientific literature that defines the criteria to determine whether a biofuel is sustainable. For example, the EU Directive 2009/28/EC (RED) on the promotion of the use of energy from renewable sources includes mandatory sustainability criteria. Compliance with these criteria is standard practice, or sustainability-as-usual, to European biofuel producers. In 2013, the EU produced 252 Mtoe of biofuels, of which at least $10 \%$ was subject to the RED sustainability criteria [2]. The publication of the global standard ISO 13065 sustainability criteria for bioenergy in 2015 could increase global awareness of the sustainability issues associated with bioenergy. Furthermore, several sets of ecological, social and economic sustainability Principles, Criteria and Indicators (PCI) have emerged in the scientific literature [3]. However, biofuel producers that rely solely on the externally set standards for sustainable biofuels have only taken the first step on the path towards more mature corporate responsibility for sustainability and sustainability excellence.

Research has identified deficiencies in the sustainability PCI and assessments of bioenergy systems. Awareness of the deficiencies could be useful to biofuel producers that are seeking further opportunities to achieve sustainability excellence and develop more sustainable bioenergy systems. The current PCI and the scientific sustainability assessments of bioenergy concentrate on limited sustainability issues such as greenhouse gas emissions and energy balance [4]. Research has clearly stated that more holistic sustainability assessments of bioenergy systems are required to avoid problem shifting [5]. The provision of biofuel is an important ecosystem service [6]. However, it has the potential to compromise other ecosystem services, especially in the food-water-energy nexus, such as local food, feed, fuel wood and freshwater resources [7]. Also conflicting views have emerged. For example, Dias et al. [8] concluded that it is not possible to establish a significant correlation between an increase in food prices and biodiesel production. Furthermore, they suggested that biodiesel cannot only be said to deprive food crops of land because food waste occupies more land than biodiesel crops [8]. Thus, a systemic view and awareness of possible global and local sustainability challenges and trade-offs could be of use to biofuel producers that strive to develop more sustainable bioenergy systems.

Buchholz et al. [9] applied an adaptive systems approach to produce an integrated sustainability assessment of bioenergy systems. In their sustainability assessment of biobutanol, Niemistö et al. [10] concluded that the manufacturing process should not be considered in isolation from the surrounding society, and that the concept of value added in the operational environment is an important component of sustainability. Kettl et al. [11] continued that, in the context of regional energy systems, ecological impacts should be evaluated simultaneously alongside the creation of local value. Thus, the view of value creation opportunities is a further aspect that biofuel producers should take into consideration when developing more sustainable bioenergy systems.

The concept of corporate responsibility for sustainability has attracted attention in scientific literature. For example, Dyllick and Hockerts [12] and Ketola [13] address corporate sustainability, and its different levels, which Baumgartner and Ebner [14] and Dyllick and Muff [15] refer to as levels of maturity. Research has explored how a "truly sustainable business" [15] can be characterised and what efforts and developments business operators need to consider on the path towards achieving such sustainability excellence. 
Dyllick and Muff [15] and Whiteman et al. [16] discussed that the efforts business operators invest when attempting to enhance sustainability management are typically disconnected from macro-level sustainability challenges. This disconnect prohibits business operators from achieving the most mature level of corporate responsibility for sustainability [15]. In other words, the question of how a business can contribute to solving the urgent sustainability challenges of contemporary society with its products, services and activities is most relevant at the most mature level of corporate responsibility for sustainability [15]. Although general company profiling with regard to corporate responsibility for sustainability has been a research interest for some time, the application in the bioenergy sector is limited.

The objectives of this study were to characterise the maturity levels of corporate responsibility for sustainability in the context of bioenergy systems and biofuel producers and to outline an approach for bioenergy businesses to follow at the most mature level of corporate responsibility for sustainability. The results should provide information about how bioenergy business could change its perspective from sustainability-as-usual to sustainability excellence.

A review of literature laid the theoretical foundation for this study, complemented by the findings of three workshops that were attended by bioenergy sustainability experts. The literature and the findings of the workshops were further analysed to characterise the maturity levels of corporate responsibility for sustainability and to create an approach by which sustainability excellence can be achieved. A theoretical case study was conducted to drive deeper insights into the local context.

\section{MATERIALS AND METHODS}

Scientific and other literature laid the foundation for this study through providing a broad definition of the maturity levels of corporate responsibility for sustainability and determining the relevant components of a systematic business approach to macro-level sustainability challenges and opportunities. A participatory approach, cf. [17]; i.e., workshops attended by bioenergy experts, was utilised to collect data about the maturity levels of corporate responsibility for sustainability in the bioenergy context and to outline the business approach required to operate at the most mature level of corporate responsibility for sustainability. The data that was used to characterise the maturity levels consisted of sustainability questions from the context of a case study of Brazilian biobutanol and methods and tools for sustainability management.

\section{Workshops}

Three workshops were organised during 2013 and 2014 for Finnish bioenergy company representatives and bioenergy researchers. The participating companies' business activities covered the whole supply chain from biomass cultivation to energy production. Table 1 shows the number and type of participants in each workshop.

Table 1. Workshop participants

\begin{tabular}{cccc}
\hline \multirow{2}{*}{$\begin{array}{c}\text { Type of } \\
\text { participating organisation }\end{array}$} & \multicolumn{3}{c}{ Number of participating organisations (Number of participants) } \\
\cline { 2 - 4 } Workshop 1 & Workshop 2 & Workshop 3 \\
\hline Research institute & $8(15)$ & $7(10)$ & $5(7)$ \\
or consultant & $3(3)$ & $2(2)$ & $2(2)$ \\
Biofuel producer & $1(1)$ & $1(1)$ & 0 \\
Technology provider & $3(7)$ & $2(3)$ & $4(5)$ \\
Bioenergy producer & $2(2)$ & $1(1)$ & $1(1)$ \\
Other & $17(28)$ & $13(17)$ & $12(15)$ \\
\hline Total & & &
\end{tabular}


Table 2 shows the data that was collected during the group discussions that were held in each workshop.

Table 2. Data collected from the workshops

\begin{tabular}{ccc}
\hline Workshop & Number of data & Description of data \\
\hline \multirow{2}{*}{ Workshop 1 } & 407 & Sustainability aspects \\
Workshop 2 & 166 & Methods/tools \\
& 206 & Sustainability questions \\
Workshop 3 & 14 & Efficiency measures \\
& 16 & Value creation measures \\
& 4 & Methods/tools \\
\hline
\end{tabular}

Workshop 1 concentrated on the general sustainability indicators of bioenergy systems and on identifying methods and tools by which sustainability can be managed. A depiction of a general three-stage bioenergy life cycle was used, and sustainability indicators, methods and tools were collected for each stage of this life cycle. The participants had different perceptions of the term "indicator". Thus, the collected indicators included different sustainability aspects that were further classified into impact categories, criteria, indicators, decision-making questions about practical choices in the production chain, and observations of the production chain. The sustainability aspects were previously broadly classified into different levels of corporate responsibility for sustainability in [3]. The methods and tools were classified to characterise the different maturity levels of corporate responsibility for sustainability.

Workshop 2 concentrated on local sustainability questions in the operational environment of the Brazilian biobutanol case study. During Workshop 2, a description of a four-stage biobutanol life cycle and its operational environment, together with a list of ten relevant bioenergy sustainability themes were utilised as supporting material to facilitate the composition of lists of local sustainability questions for different stages of the life cycle. The ten themes were compiled using the data that were gathered in Workshop 1: acceptability, requirements from legislation, standardisation and certification systems, economic steering, raw materials, productive goods, production technology, resource consumption, ecological impacts, social impacts, and economic impacts. The themes covered the major sustainability themes that have been described in existing literature [3]. The sustainability questions were classified to characterise the maturity levels.

Workshop 3 discussed the different maturity levels of corporate responsibility for sustainability and examined how the local sustainability questions of the biobutanol case study from Workshop 2 could be divided into two maturity levels: efficiency measures and value creation measures. This dichotomy was based on the "two waves of sustainability" presented, for example, by Schumpeter [18], and applied within the business world. For example, Henkel's [19] sustainability strategy consists of two layers: creating more value for stakeholders and reducing footprint. As such, this strategy incorporates both the efficiency and value creation measures of sustainability. Another example that supports this view is that of BASF, which also presented a twofold sustainability strategy in 2010: creating value, and thus, for example, accessing new markets and retaining customer relations while, at the same time reducing the risks related to legislative requirements, materials and reputation [20].

\section{Case study}

A theoretical case, in which biobutanol is produced from sugarcane in Brazil and imported to the EU market for use as a transportation fuel, was employed to gain contextspecific insights into the sustainability questions associated with bioenergy systems. 
A systematic life cycle approach was used as a basis for the case study. The advantages of this approach were that the life cycle assessment is standardised [21] and commonly used in the assessment of potential environmental impacts [4]. Furthermore, a life cycle approach can be applied to social and economic impacts [21]. Social impacts can be linked to the conduct of companies in the supply chain [22], and economic impacts can be linked to the life cycle unit processes [23]. A life cycle approach provides a holistic view of the product system that enables the observation of trade-offs and helps avoid problem shifting between life cycle stages [24]. Figure 1 shows the biobutanol life cycle that was considered in Workshops 2 and 3.

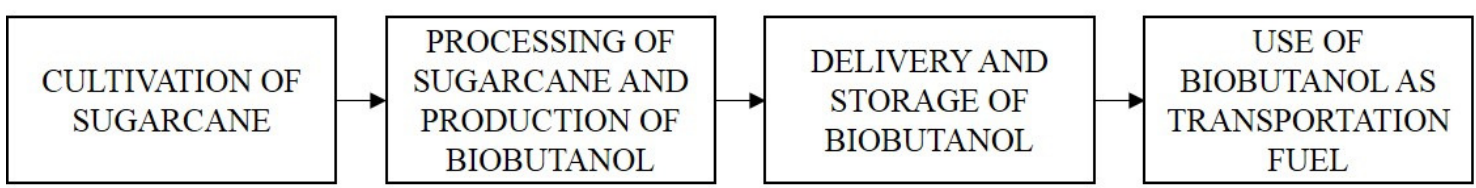

Figure 1. The biobutanol life cycle stages

Ethanol can be utilised as an alternative to fossil petrol in vehicles. However, due to the differences in fuel characteristics, the maximum share of ethanol with petrol is approximately $10 \%$ in non-flex-fuel vehicles. As such, higher biofuel shares in existing vehicles require alternative biofuel options. Biobutanol can be used in higher percentage in combination with petrol than ethanol. The Acetone-Butanol-Ethanol (ABE) fermentation is the most common butanol production process [25], which was described, for example, by Mariano et al. [26]. During ABE fermentation, bacteria produce acetone, butanol, and ethanol from starchy feedstock [27]. The feedstock used during the ABE fermentation is similar to that employed during the ethanol process; for example, corn [25] and sugarcane [26]. Brazil has significant experience in the production of ethanol from sugarcane and the use of bagasse combustion to generate the electricity and heat required during the ethanol production processes [26]. Figure 2 presents the process by which $\mathrm{ABE}$ is fermented from sugarcane based on the work of Wu et al. [25] and Efe et al. [28].

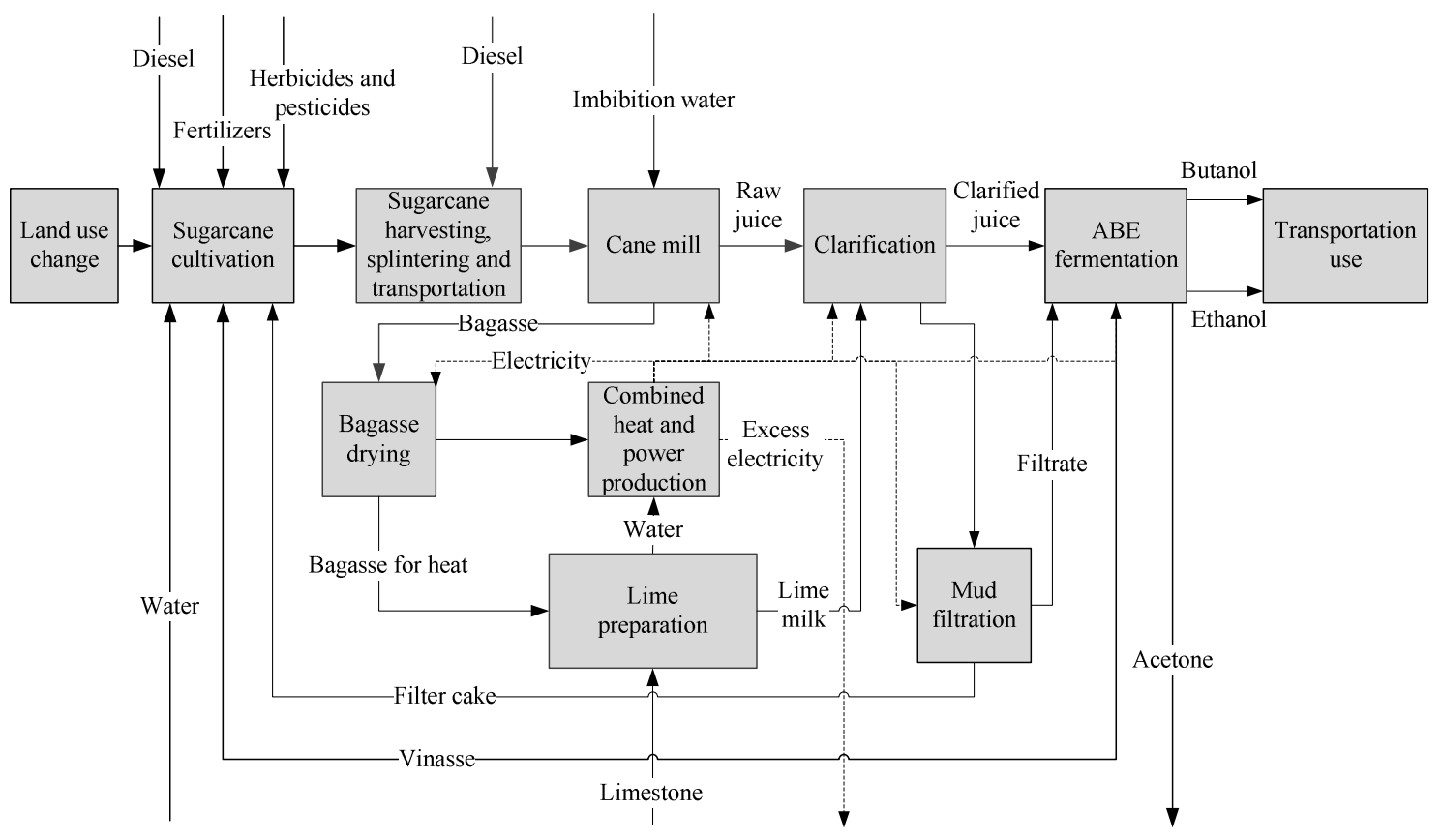

Figure 2. Biobutanol production process (adapted from [25] and [28]) 
In the theoretical case study, a bioenergy company based in Europe is planning to invest in an ABE biobutanol plant that will have an annual production capacity of 100,000 tonnes of biobutanol. The plant will be located in Brazil, and the intended raw material of biobutanol is Brazilian sugarcane. Brazil is an attractive area in which to produce bioethanol, and the production costs in this region are approximately half those of the EU [29]. The sugarcane will be cultivated on land that the bioenergy company leases from local authorities. The land area is located in the tropical savannah of Cerrado. Sugarcane cultivation is rapidly expanding to the Cerrado area [30] due to governmental steering. At present, a few local cattle farmers utilise the land as pasture [30], and it is not actively utilised for agricultural purposes; as such, the soil will need to be prepared before sugarcane cultivation can commence. A labour force needs to be brought into the area, and the necessary supporting infrastructure will need to be constructed. By-products of sugarcane cultivation can be utilised to produce energy for pre-processing and the ABE process in a similar way to ethanol production processes [28]. Biobutanol will be fully refined in Brazil, transported by trucks to the coast and exported by tankers to the EU market. According to a preliminary life cycle assessment study, the fuel complies with the RED sustainability criteria. The European bioenergy company may, however, have quite different thoughts, activities and communication related to sustainability based on the level of maturity of its responsibility for sustainability. This study aims to characterise these different levels, especially the highest level at which the business contributes to solving macro-level sustainability challenges.

\section{THE MATURITY LEVELS OF CORPORATE RESPONSIBILITY FOR SUSTAINABILITY}

Company maturity profiling was first performed as early as the 1980 s with regard to market position [31] and strategic management [32]. Research has continued to incorporate profiling in the areas of environmental strategy [33], corporate social responsibility [34], and sustainability, as can be observed in the work of Baumgartner and Ebner [14] and Dyllick and Muff [15]. Figure 3 shows an indicative model of the maturity levels of corporate responsibility for sustainability. Figure 3 is based on information from various literature sources and is explained in more detail below.

Heikkurinen [35] suggested that corporate responsibility has two orientations: extrinsic stakeholder responsibility and intrinsic corporate responsibility. Extrinsic responsibility implies that external requirements steer sustainability operations, whereas intrinsically responsible companies show creativity in sustainable solutions. Therefore, the intrinsic orientation implies that a more mature level of corporate responsibility for sustainability has been achieved. In Figure 3, the acceptability orientation is directly related to extrinsic stakeholder responsibility. In the profitability orientation, the extrinsic source of responsibility is shareholders, which is one stakeholder group. The sustainability orientation is based on the intrinsic corporate responsibility.

The dashed lines in Figure 3 imply that companies most probably combine the orientations so that they exhibit different levels of maturity with regard to different aspects of sustainability [14]. The geographical location of operations and different societal conditions could be one explanation for variations in maturity. Although companies would ideally always mature in corporate responsibility for sustainability, the shifts between the maturity levels can be non-linear and bidirectional. Ideally, the business should exhibit the resilience to continue on its selected sustainability path despite societal and environmental changes. However, in practice, for example, in economically difficult times, an organisation's strategic activities tend to regress to a business-oriented survival strategy, and environmental efforts are treated as a lower priority [36]. As explained above, the shift between profitability or acceptability and 
sustainability orientation is quite significant in terms of the source of responsibility and the conception of sustainability, which will be explained below.

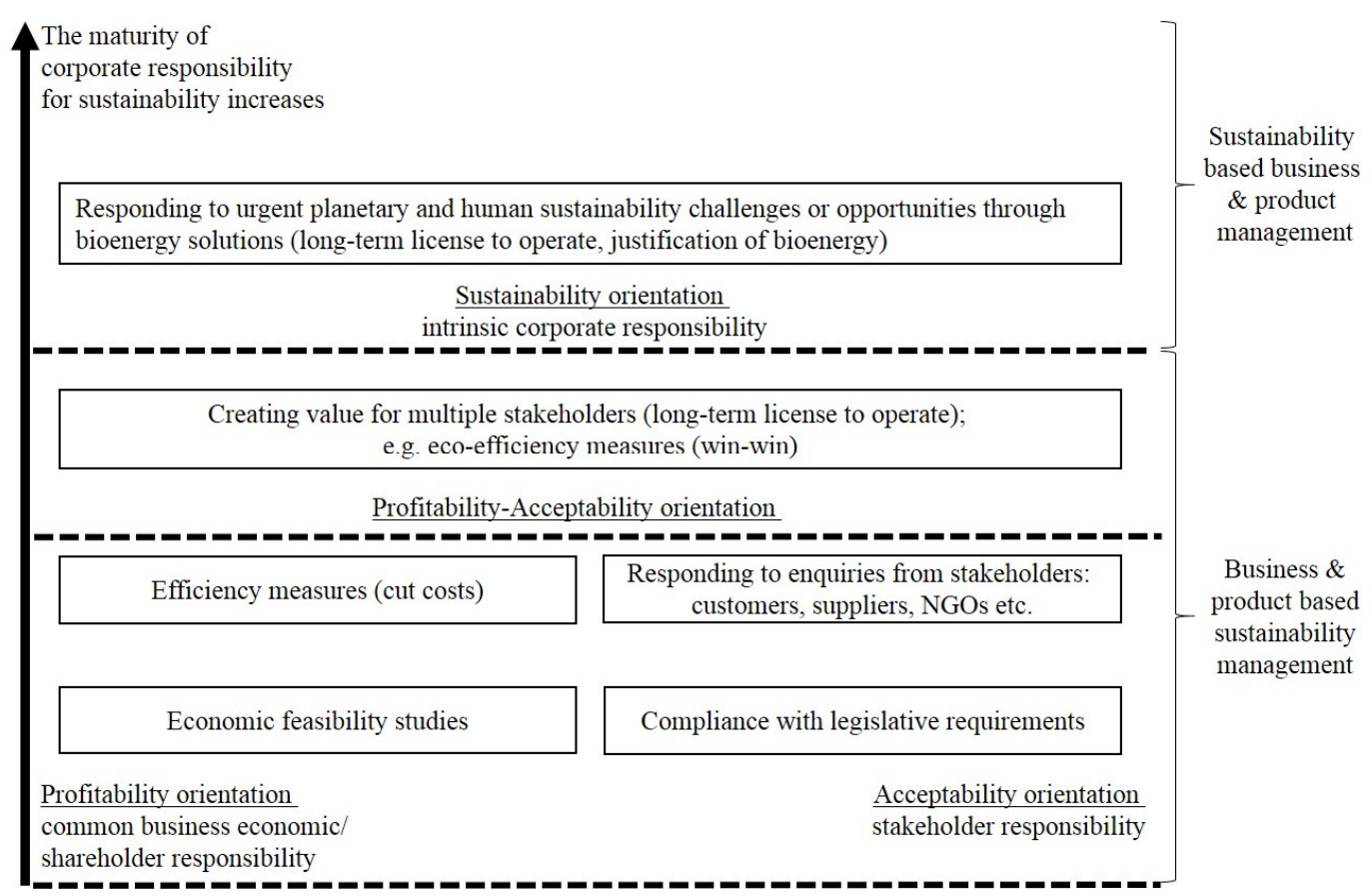

Figure 3. A model of the maturity of corporate responsibility for sustainability, the boxes describe the activities (and objectives) of primary interest at different levels

How do different conceptions of sustainability relate to the model of the maturity of corporate responsibility for sustainability? In general, literature identifies two conceptions of sustainability: weak and strong [35], or, as Ketola [13] correspondingly states, the two conceptions of corporate sustainability: relative and absolute or universal sustainability. Weak or relative sustainability allows sustainable economic growth [13] and a large rate of substitution of natural capital, e.g. ecosystem services [37], by human capital [35], e.g. technological solutions [13]. Relative sustainability concentrates on the stakeholders' material welfare [13]. Weak sustainability is a traditional company approach to sustainability [13]. Heikkurinen [35] stated that the levels of extrinsic responsibility and economic instrumentalism, which are conventional approaches to corporate responsibility, are based on weak sustainability. This is the current state of the sustainability-as-usual approach.

Strong or absolute sustainability recognises critical natural capital [37]. It incorporates systemic thinking and the idea that society and the economy are dependent subsystems of the environment or planet Earth; as such they have physical limits [35]. Strong sustainability does not approve quantitative economic growth, but instead, concentrates on qualitative improvements to the well-being of humans and nature [13]. In comparison to relative or weak sustainability, the absolute or strong conception of sustainability incorporates the idea of sufficiency as opposed to the maximisation of profit or benefit [13]. The sustainability orientation in the model of the maturity of corporate responsibility for sustainability applies the ideology of strong sustainability and represents sustainability excellence. However, an intrinsic conflict exists between the original purpose of business, to produce profit and the abolition of economic growth.

\section{The profitability orientation}

Economic feasibility studies represent a basic business procedure that is driven by common business economic or shareholder responsibility. Schumpeter [18] suggested 
that efficiency thinking represents a traditional business approach to sustainability. Companies could initiate efficiency measures for sustainability from a purely businesseconomic starting point; i.e., for cutting costs, with potential simultaneous positive impacts on decreasing the environmental loading. However, cost-cutting exercises could have a reverse effect on environmental protection because companies that are focused on cost reduction are less likely to adopt environmental values or policies [36].

\section{The acceptability orientation}

Typically, a company actively takes into account more stakeholder groups as the corporate responsibility for sustainability grows in maturity [35]. For example, with regard to the supply chain stakeholders, the sustainability goals and objectives set by a company tend to extend beyond the company's own activities to the whole supply chain as the corporate responsibility for sustainability grows in maturity [38].

Compliance with legislative requirements is the prerequisite for business continuity and for reaching higher maturity levels [14]. However, Papagiannakis et al. [39] found that business activities that are merely aimed at complying with legislation delay the transition towards sustainability. In addition, different stakeholder or interest groups have different requirements and expectations. Literature suggests that bioenergy systems tend to fail if the concerns of stakeholders have not been taken into consideration within an informed decision-making process, since stakeholder participation provides information about the sustainability impacts of the system; for example, the risks and values to different stakeholders [9].

Requirements, for example, regulations, are commonly used in economic system modelling [40]. Requirements could represent the rules, criteria, orders, and requests that different stakeholders have specifically issued. A company could either take a reactive or proactive stance to requirements. A proactive approach to stakeholder requirements could increase as the corporate responsibility for sustainability grows in maturity [41]. Stakeholder expectations are not (yet) issued and could thus be more difficult for companies to detect. As such, they always require a proactive approach.

It is worth considering, whether higher overall maturity in sustainability matters leads to more proactivity with regard to requirements or vice versa. Buysse and Verbeke [41] found that stronger environmental proactivity is likely to lead to more sensitivity to stakeholder requirements and more pressure from stakeholders might lead to a more proactive environmental strategy.

\section{The profitability-acceptability orientation: creating value for multiple stakeholders}

More mature companies might deliberately seek win-win situations through the simultaneous reduction of footprint and costs; i.e., through eco-efficiency measures. Ketola [42], however, stated that companies rarely take responsibility for the environment, society or culture, unless economic benefits are expected. Dyllick and Muff [15] suggested that more mature companies set targets and consciously attempt to create value for several stakeholders.

The sustainability goals and objectives set by a company tend to change from being cost-, efficiency- and regulatory compliance-oriented to more widely environment- and society-oriented as the corporate responsibility for sustainability grows in maturity [18]. Here, the company perspective shifts from short-term profits to long-term license to operate [18], or respectively, from short-term to long-term sustainability concerns [15] as the corporate responsibility for sustainability grows in maturity. The shift begins when stakeholder requirements are addressed more proactively.

The question as to whether value creation is directed towards material and monetary or immaterial value, could define whether the sustainability conception of the company is weak or strong, respectively. 


\section{The sustainability orientation}

Figure 3 describes the shift in the perspectives of sustainability management [15] so that as corporate responsibility for sustainability matures towards the creative, intrinsic corporate responsibility level driven by strong intrinsic motivation, business and productbased sustainability management converts to sustainability-based business and product management.

The sustainability-oriented business recognises the boundaries of sustainable business and applies the ideology of strong sustainability. As stated in the introduction, Dyllick and Muff [15] and Whiteman et al. [16] highlighted the disconnect between business operations and macro-level sustainability challenges represents a major deficiency in the corporate responsibility for sustainability. The need to connect business operations with local sustainability challenges could be further extended to incorporate micro, meso, macro and planetary levels [35].

The planetary boundaries first described by Rockström et al. in 2009 [43] and further developed by Steffen et al. in 2015 [44] represent the universally recognised global environmental sustainability challenges and set the safe limits for sustainable human activities on planet Earth. The planetary boundaries can be further translated into local context by defining the local environmental ceiling [45]. The boundaries of a sustainable and just business could be extended from the environmental ceiling to human needs, both general and locally specific, that determine the minimum social foundation for well-being [45]. In Life Cycle Assessment (LCA), the limits of safe and just human activities are referred to as areas of protection [46] or as safeguard subjects [47], and they commonly include the following five categories: natural environment quality [46], natural resources [46], man-made environment [46], human health [46], and human dignity and well-being [22]. Figure 4 depicts the limits of the operational environment of a sustainable business, which is defined by the sustainability principles: to ensure the well-being of humans within the local environmental ceiling and planetary boundaries [45].

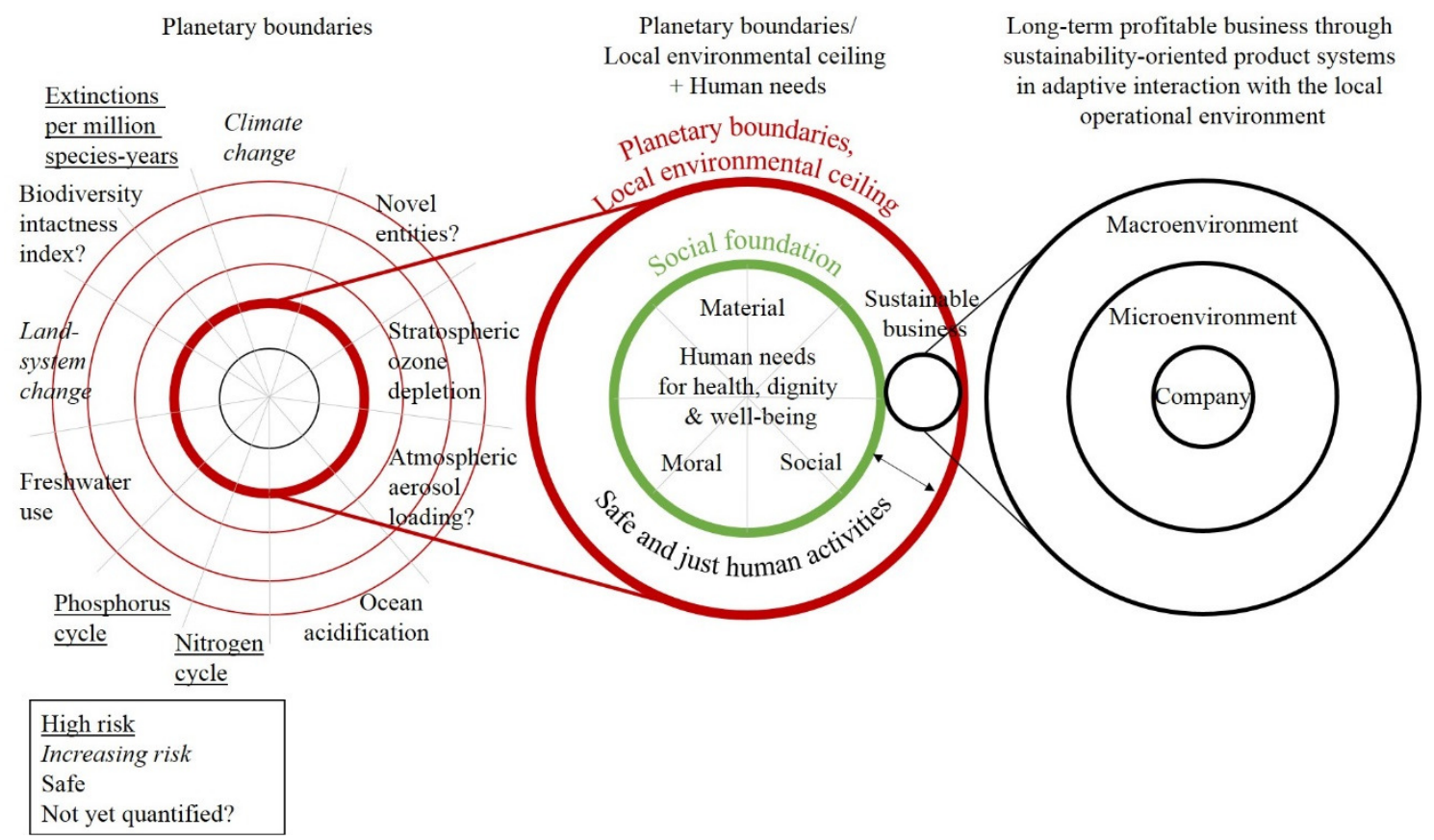

Figure 4. Boundaries of sustainable business, sustainable business occurs within the boundaries set by the environmental limits and social foundation (adapted from [34, 35, 43-45, 48, 49])

Rockström et al. [43] and Steffen et al. [44] described how population growth and increases in the standard of living are common factors that contribute to the challenges 
that emerge when attempting to operate within the planetary boundaries. Such macrolevel developments could be a business interest within the development of long-term strategies. At the macro level, the analysis of Political, Economic, Social, Technological, Ecological (PESTE) factors is a common business practice [50]. Operations at the local level contribute to global sustainable or unsustainable development.

From an anthropocentric perspective, the social foundation of sustainable human operations is firmly grounded in human needs. Well known need theories include Maslow's hierarchy of needs and Max-Neef's matrix of needs [49]. The minimum level in the fulfilment of needs, the social foundation, should be achieved. This is marked in the colour green in the middle sphere of Figure 4. Material needs include the requirements for food, water and shelter; moral needs include needs the requirements for truth and justice; and social needs include requirements for respect and belonging [49]. Human needs create a local demand for products and services. It is common for businesses that follow responsible business practices to identify the stakeholders that have subjective needs and interests that translate into requirements at different levels of the business operational environment [41].

\section{RESULTS AND DISCUSSION}

The following subsections will discuss the maturity levels of corporate responsibility for sustainability. The subsections will provide examples of sustainability questions, themes, objectives, methods and tools at the levels of profitability, acceptability and profitability-acceptability orientation. The last subsection will discuss the sustainability orientation together with the approach for bioenergy businesses to operate at the level of the sustainability orientation.

The appendix contains all the local sustainability questions that were collected during Workshop 2. The questions are divided according to the levels of the model of the maturity of corporate responsibility for sustainability. The sustainability questions were retrieved within a few hours' work; as such, the list of questions is incomplete, although missing data is difficult to identify. The discussions about relevant sustainability themes and methods in Workshop 1 remained at a general level and are inevitably deficient; however, the workshop themes covered the major sustainability themes presented in literature [3] and all maturity levels. The sustainability questions provided a view of the extent to which sustainability considerations are required at all life cycle stages. The sustainability questions encompassed a wide range of topics suggesting that a multidimensional approach could be useful to generate ideas about sustainability. Furthermore, the lists of versatile sustainability questions, as well as the selection of different methods and tools, indicate that multiple tools are necessary for measuring, indicating, and managing sustainability issues. Many of the collected sustainability questions apply to bioenergy chains in general and are, therefore, not exclusive to the biobutanol chain in the Brazil and EU conditions. This study was conducted predominantly from the Finnish bioenergy business operators' perspective. Thus, other international bioenergy operators could raise more sustainability questions from alternative perspectives in further studies. Advanced conclusions about the maturity level of the Finnish bioenergy business cannot be drawn from the results.

\section{The profitability orientation}

Economic feasibility studies and calculations can be considered to represent valid methods by which profitable biobutanol business in the local societal and environmental conditions can be achieved. Figure 5 presents a summary of sustainability questions and themes for which the economic feasibility could be calculated to ensure profitability. The sustainability questions in Figure 5 include all the applicable sustainability questions that 
were generated during Workshop 2 and divided according to the themes. The extra themes come from the discussions that took place in the other workshops.

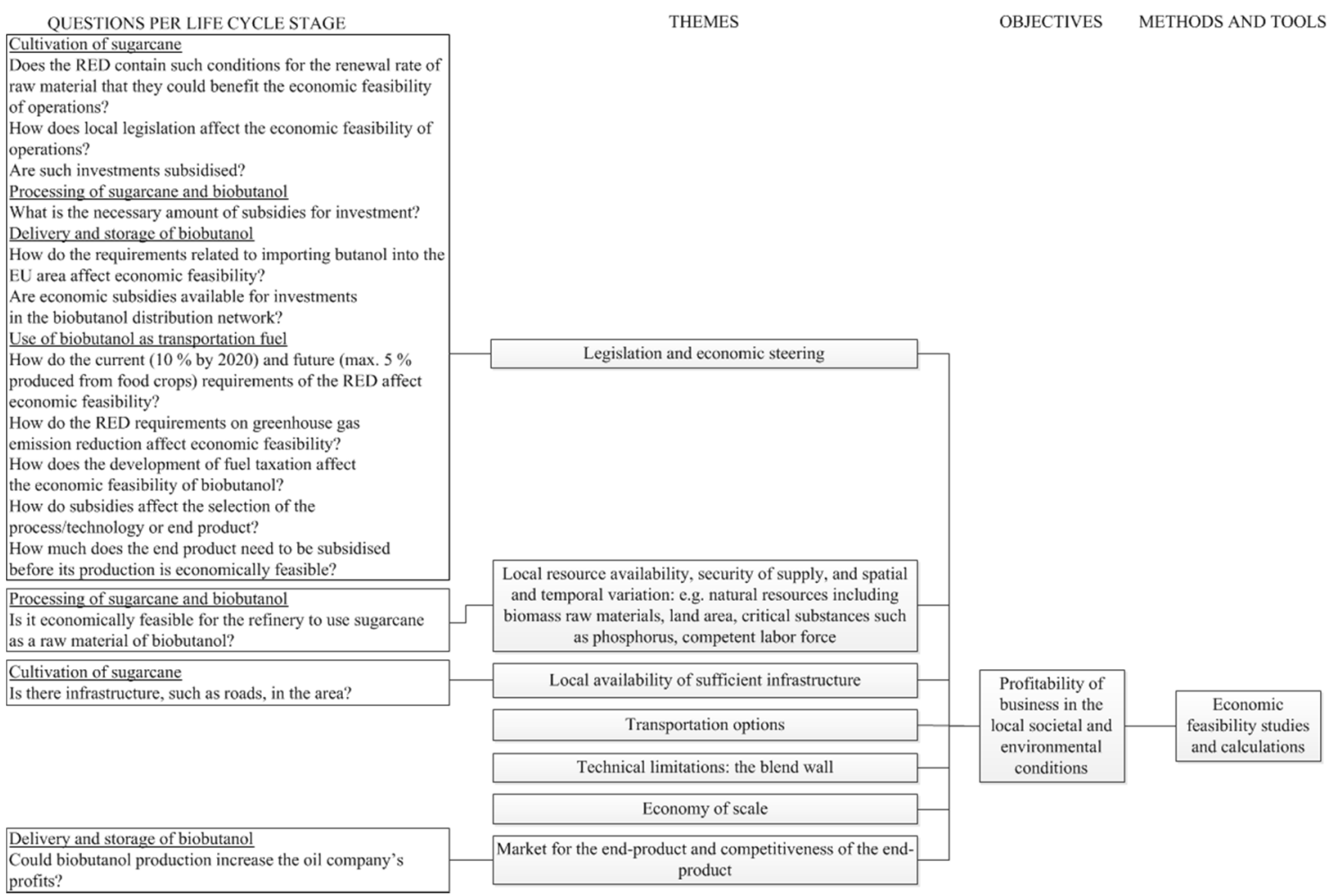

Figure 5. Sustainability questions and themes related to the objective of profitability of biobutanol business and the method of economic feasibility studies and calculations

Legislation and economic steering were emphasised in the economic feasibility studies. This emphasis implies that the profitability of biobutanol business could depend on legislative steering and political goals. Thus, in addition to the responsibility for sustainability, the economic feasibility could be shifted to societal legislative systems. The other sustainability questions concentrate on technical aspects of the production process. The maturity level of economic feasibility studies is relevant in all stages of product maturity from planning investments to expanding an existing business. The answers to the sustainability questions consist of highly quantitative information and numerical indicators.

A further method by which the business economy can be improved is through the application of different efficiency measures that, from a business perspective, primarily lead to cost savings and secondarily to other environmental and societal benefits. Thus, the business economy is seen as the endpoint of the impact pathway of the efficiency measures. Figure 6 presents the themes of efficiency measures, efficiency objectives and a selection of methods and tools that could be utilised to improve efficiency as a means of cutting costs.

Efficiency measures could be most relevant at the product maturity stage, in which the bioenergy operations are already running. Efficiency measures could improve economic and environmental performance, and this level of maturity includes environmental assessment methods.

Sustainability questions originating purely from business economic efficiency objectives and footprint reduction objectives that lead to win-win situations for the business economy and different stakeholders were difficult to distinguish. However, the questions could be answered from either a business economic or eco-efficiency 
perspective. To define the cost-cutting objectives, information about the current situation needs to be collected. For example, a simple numerical answer is required to answer the question about how much land the delivery and storage of biobutanol require. The sustainability questions could also be drivers for taking efficiency measures; for example, understanding the extent to which sugarcane cultivation competes with food production for land area would provide insights into the business economic risk related to the demand and valuation of land area.

Cost-cutting opportunities can be identified from a variety of different perspectives. For example, the sustainability questions about water in the cultivation life cycle stage included questions about whether irrigation is necessary, which water resources are used for irrigation, whether surface water or groundwater use can be reduced, and whether the water resources are temporally or spatially distributed. The water costs could be eliminated if precipitation provides enough irrigation water; if not, costs could potentially be decreased by comparing water sources. The temporal and spatial distribution of water could put a continuous water supply at risk, which could lead to production disruptions at any stage of the life cycle and represent a financial risk if not taken into consideration. Whether the objectives are reached can best be verified through quantitative data and numerical indicators; however, the calculations also require background data about process optimisation and the principles of environmental efficiency.

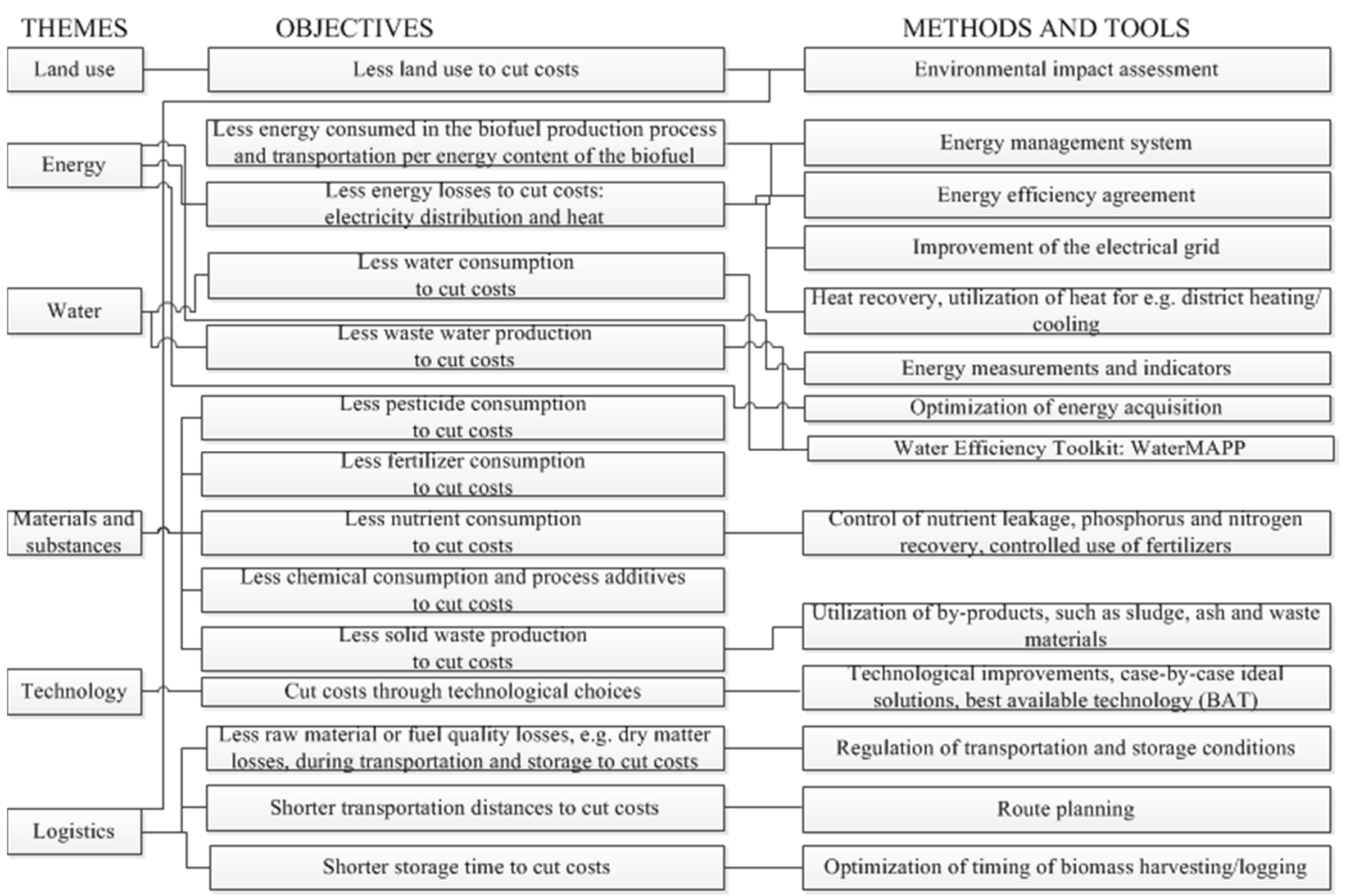

Figure 6. Efficiency themes, objectives to cut costs, methods and tools

\section{The acceptability orientation}

Figure 7 shows two different stances, reactive and proactive, to legislative requirements, examples of subject areas of legislative requirements, and a selection of methods and tools that could be utilised in the management of the requirements.

Both reactive and proactive stances to legislative requirements were discussed during the workshops. This study did not address the question as to whether a reactive approach in some sub-areas of sustainability, such as legislative or stakeholder requirements, would be sufficient while other areas required a proactive approach. 


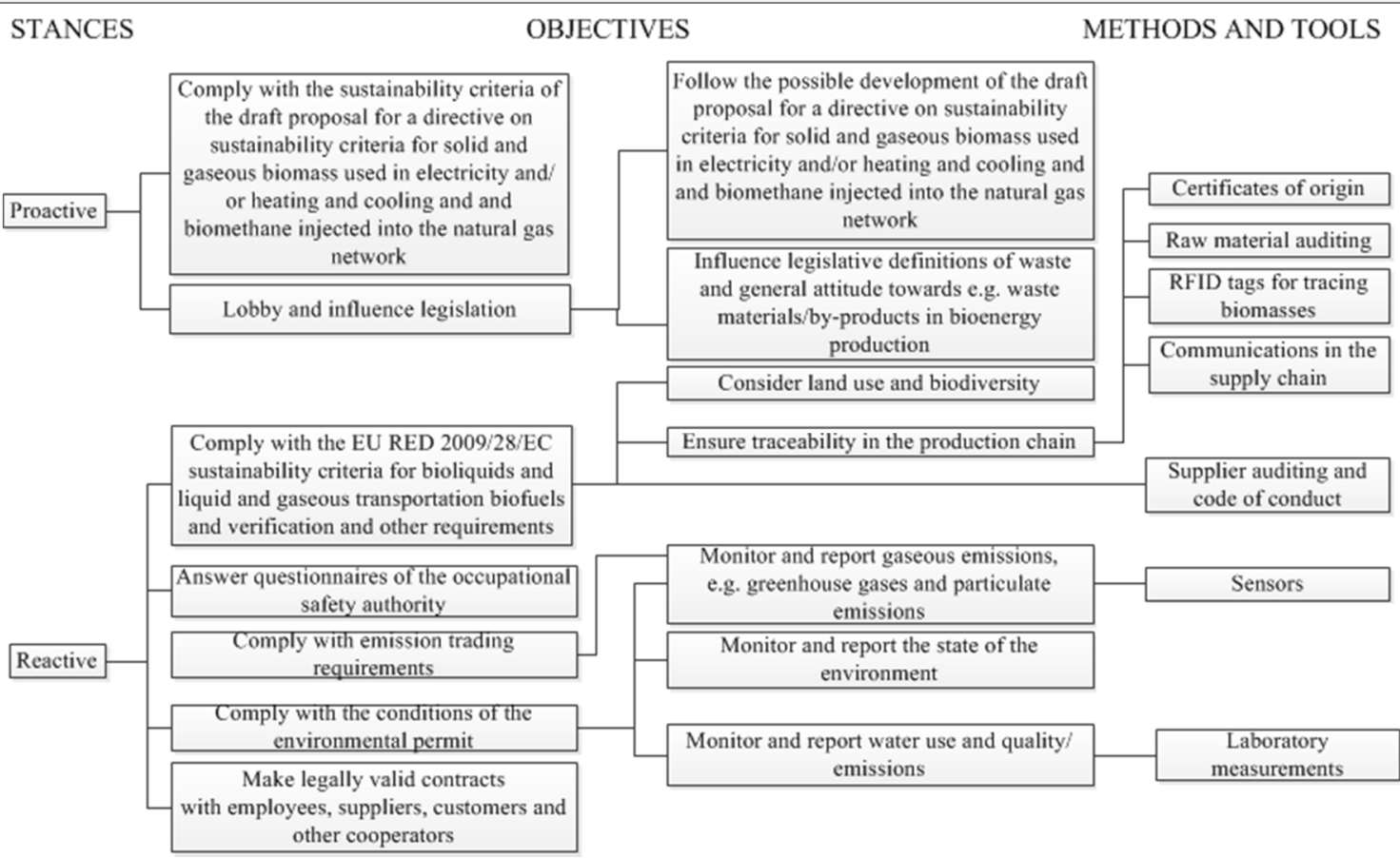

Figure 7. Stances to legislative requirements, their objectives, methods and tools

To some extent, the workshop participants seemed to emphasise the role of political targets and legislative steering in the promotion of the sustainability of bioenergy systems and bioenergy business; i.e., shifting the responsibility for sustainability to societal systems instead of taking intrinsically motivated responsibility for sustainability. They mentioned taxes and subsidies as important steering instruments at the energy system level and sustainability criteria at the level of improving existing bioenergy chains. Furthermore, the workshop participants emphasised the aspect of lobbying and influencing legislation to avoid unwanted requirements and impacts on the industry. Many organisations, however, lack sufficient resources.

Although the workshop participants seemed to shift the responsibility for sustainability to legislative systems to some extent, an alternative perspective arose. The workshop participants did not perceive stringent legislation as favourable because it restricts business opportunities and opportunities for creativity, the latter of which is particularly important at the level of sustainability excellence. The same notion applies to the quantity of legislation. The workshop participants considered "extensive bureaucracy", "over regulation" and the "jungle of regulations" as burdensome, even suppressing, for the bioenergy business. Some participants were also concerned about the limited scope of the current sustainability criteria that possibly leads to sub-optimisation instead of holistic optimisation. However, over regulation could lead to problematic conflicting legislative requirements. Conflicts in the requirements of different interest groups are, of course, inevitable. Furthermore, local conditions in EU countries, national interpretations of the EU-level directives, and national differences in the level of compliance monitoring, were considered to represent EU-level challenges.

No business can avoid the burden of verification of legislative compliance; legislation is essential at any stage of product maturity. It requires ensuring constant compliance with the current legislative requirements and following their development. The sustainability questions concentrated on achieving sustainability through compliance with legislation (Does sugarcane comply with sustainability criteria?), identifying legislative risks from developing legislation (Is the EU planning distribution targets for biofuels for 2020?) and risks from non-compliance to business (Are the local authorities 
authorised to lease the land?). The impact of legislation on biobutanol operations can be significant in the multitude of regulated operations. Figure 7 shows a minor part of all applicable legislation. To distinguish all legislation-related sustainability questions, an extensive review of legislation would be necessary. For example, the questions depicted the large variety of monitoring requirements set by, for example, the environmental permit. The answers to the sustainability questions would require both quantitative and qualitative indicators.

Figure 8 shows the two stances, reactive and proactive, to customer requirements, examples of the subject areas of customer requirements, and a selection of methods and tools that could be utilised. Customers are used as an example of a stakeholder group.

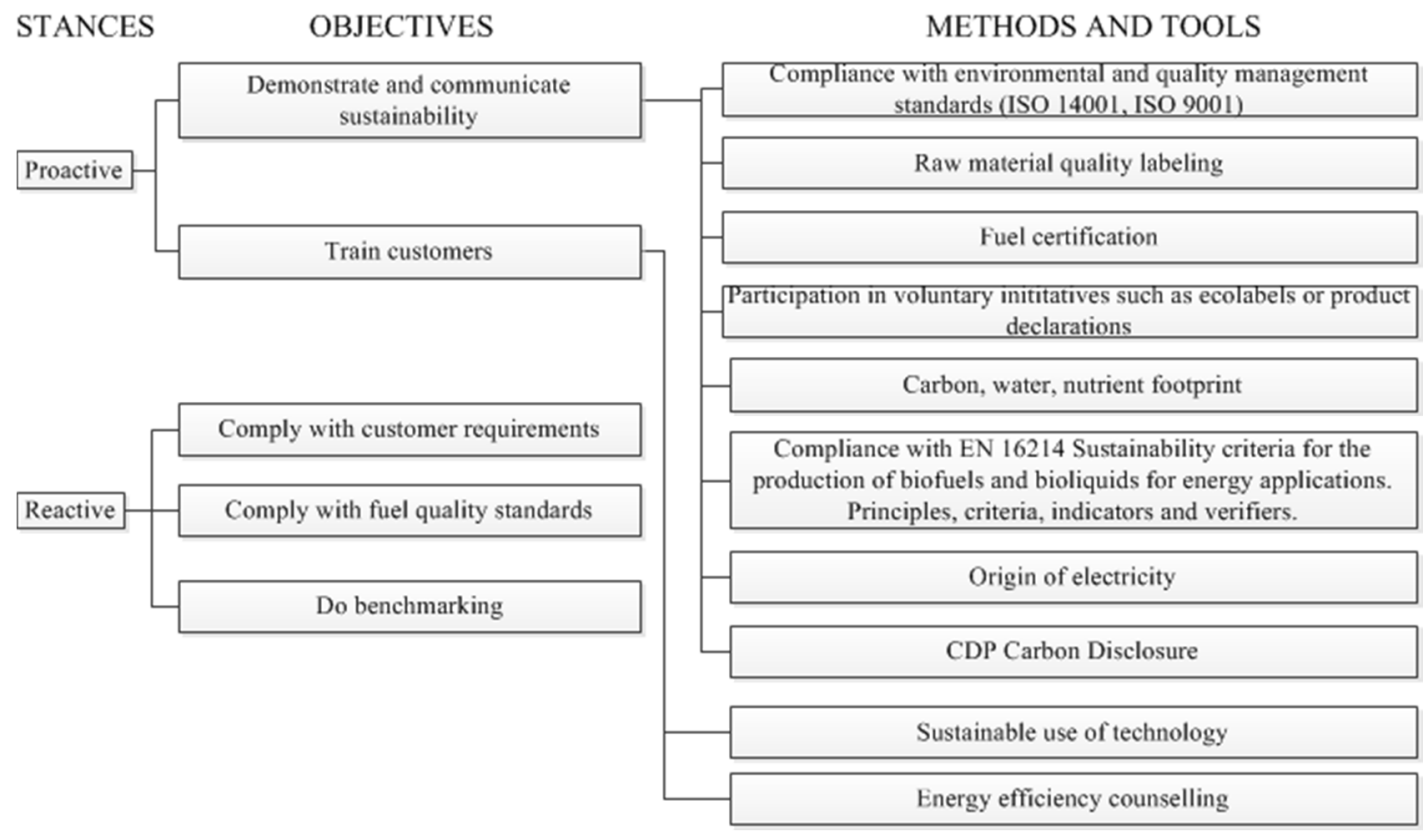

Figure 8. Stances to customer requirements, their objectives, methods and tools

Sustainability questions related to the maturity level of responding to enquiries from stakeholders showed a large variety (see appendix). Stakeholder requirements could be relevant at all stages of product maturity. The level is closely linked to the level of creating value for multiple stakeholders, although company activity at this level depends on the activity of enquiries by stakeholders. For example, the requirements of non-human stakeholders could be included only at the more mature level of creating value for multiple stakeholders.

Compliance with standard requirements could serve as a tool to encourage compliance with customer requirements and expectations (e.g., fuel quality standards) and proactively enhance acceptance among a wider stakeholder base (e.g., ISO 26000 Guidance on Social Responsibility). Voluntary standards could be used quite similarly to legislation since they include requirements and criteria, such as the sustainability criteria outlined in the ISO 13065. The workshop participants advocated for a verification of the suitability of certificates for legislative purposes. Company representatives recognised the need to influence standards respectively as they would influence legislation. The workshop participants mentioned the possibility that demonstrating compliance with legislation could be sufficient for some stakeholders, such as customers and nongovernmental organisations. However, the possibility that exceeding the legislative requirements and standards may benefit sales was acknowledged.

The profitability and acceptability orientations were somewhat easier to characterise than the more mature levels. Because solely profitability- and acceptability-related 
activities are part of everyday business operations, retaining these well-known activities in the model of the maturity of corporate responsibility for sustainability could help companies initiate more advanced sustainability activities on common, solid ground.

\section{The profitability-acceptability orientation: creating value for multiple stakeholders}

The level of value creation for multiple stakeholders in the maturity model (Figure 3) was intertwined with the level of efficiency measures in the profitability orientation and the level of responding to stakeholder enquiries in the acceptability orientation. The division of sustainability questions originating purely from business economic efficiency targets and footprint reduction targets leading to win-win situations for the company economy and different stakeholders was ambiguous. Furthermore, the stage of creating value for multiple stakeholders could include the proactive stance to stakeholder requirements. The extent to which it was difficult to distinguish the levels may also indicate that as the bioenergy operators' maturity in corporate responsibility for sustainability grows, the profitability and acceptability orientations tend to converge, as suggested in the maturity model (Figure 3 ).

When the stakeholders are considered broadly to include non-human stakeholders, and the bioenergy operator proactively considers stakeholder expectations, i.e., requirements that the stakeholders have not yet stated (or have yet to conceive) in relation to the bioenergy system, the division between the profitability-acceptability orientation and the sustainability orientation becomes blurred. Fundamentally, there would be no better way to proactively approach those stakeholder expectations than to aim at safe and just bioenergy operations within the limits set by the environmental boundaries and social foundation for human health, dignity and well-being. Therefore, such an approach would be necessary at all stages of product maturity.

A further link could be found at the level of legislative requirements. In areas of stricter legislation, certain legislative requirements represent sustainability-as-usual for the bioenergy business. However, in areas of less strict legislation, more depends on the willingness of the business operator to create value for multiple stakeholders; for example, by setting environmental quality standards. Legislative sustainability criteria could contribute to the mindset and ability of the bioenergy business to operate at the highest maturity levels of corporate responsibility for sustainability.

Although linking the sustainability questions from Workshop 2 with underlying sustainability objectives and methods was not straightforward, intentions of value creation to multiple stakeholders could be distinguished. Although the impact pathway and value network are complicated, at a minimum, they include the common areas of protection, natural environment quality, natural resources, man-made environment, human health, and human dignity and well-being as endpoints together with the business economy. The difference between value creation for multiple stakeholders and profitability-oriented efficiency measures is that the primary endpoint is not merely business economy. Figure 9 presents examples of stakeholder groups, measures of value creation for the stakeholders, and a selection of methods and tools that could be utilised at this level.

The sustainability questions often considered the negative value creation of the bioenergy operations; i.e., negative impacts to the environment and decreasing the opportunities for stakeholders. These questions could be as relevant as those of positive value creation in determining the extent to which the operations are acceptable, if a reduction in a certain value is inevitable. The level, thus, includes both value creation and value retention. One challenge associated with approaching sustainability from the stakeholders' perspective is that the subjective values of stakeholders (both human and non-human) could be in conflict. Therefore, creating value for a stakeholder could lead to the deprivation of another stakeholder: win-win situations between the bioenergy 
business and a stakeholder could transpire to be win-win-lose situations when other stakeholders are considered. Measuring the value that can be either quantitative or qualitative and perceived differently by different stakeholders is a methodological challenge.

METHODS AND TOOLS

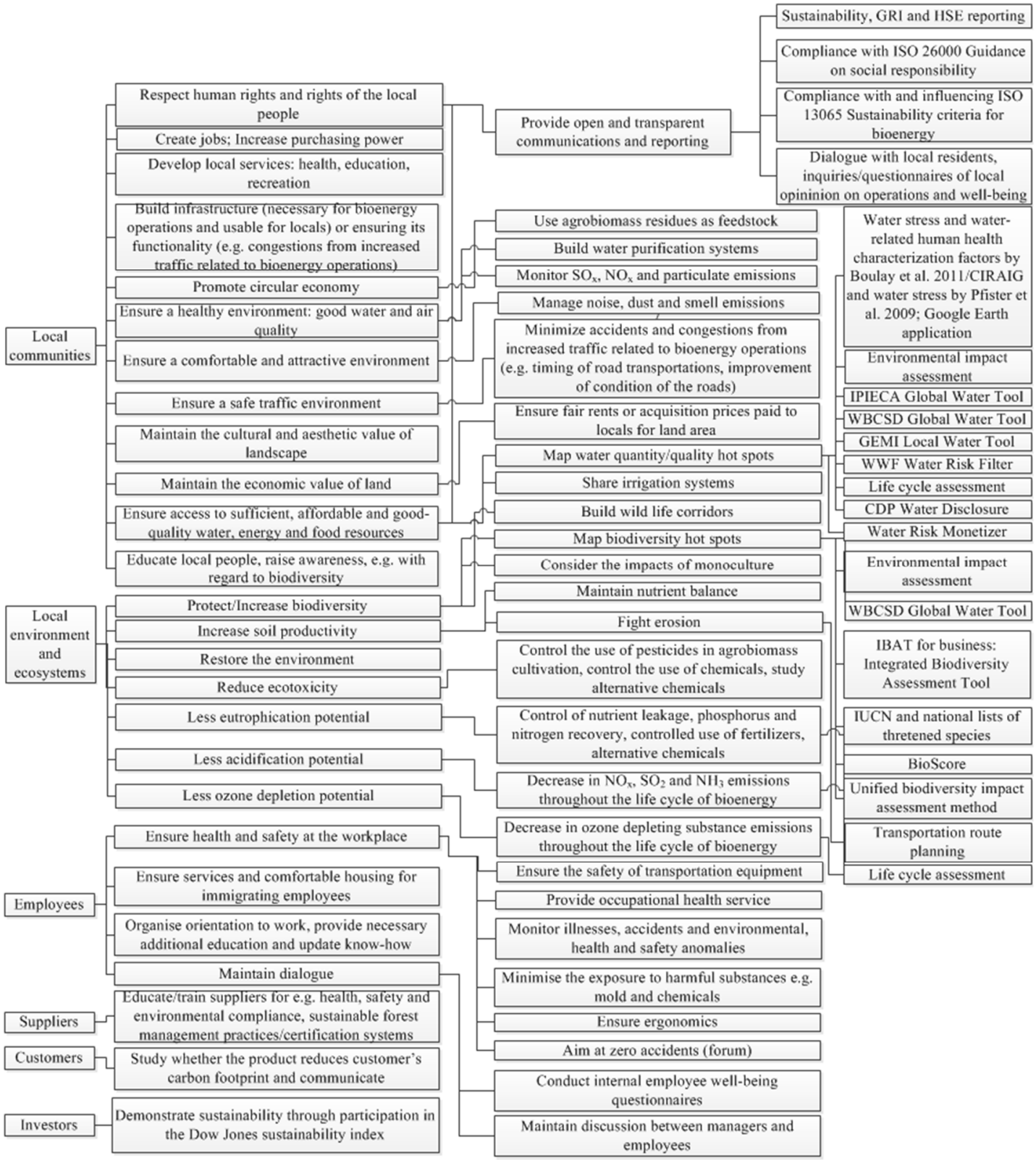

Figure 9. Multiple stakeholders, objectives that lead to value creation, methods and tools

The following paragraphs present answers to some sustainability questions at the value creation level. Machado et al. [51] concluded that the presence of sugarcane ethanol (butanol) production processes tend to improve local development as measured by illiteracy rate, Human Development Index, Theil Index (income inequality), percentage of poor people, connection to the grid and sewer system, child mortality, and life expectancy. Thus, bioenergy business operators could have a positive impact on these sustainability aspects in the long term. To answer the question as to whether additional education of employees is necessary, Herreras Martinez et al. [52] concluded in their study on the scenarios of sugarcane-ethanol production in Northeast Brazil that sugarcane operations are a significant local employer. Thus, in the event new major regional 
sugarcane operations are created, the additional education of a potentially low-qualified labour force by initiating or boosting educational programs, for example, is likely to be necessary.

When investigating the water consumption associated with sugarcane cultivation, Filoso et al. [30] found that land use changes in the Cerrado region could increase evapotranspiration rates and, thereby, potentially increase the groundwater consumption for irrigation of sugarcane. This would result in groundwater scarcity, which could be a significant risk for the sustainability of Cerrado-based biobutanol business and cause value retention. The question as to whether biodiversity decreases due to the sugarcane cultivation is related to either the level of legislative compliance or value creation. When investigating this, Filoso et al. [30] concluded that the expansion of sugarcane cultivation to regions of Cerrado threatens the biodiversity and ecosystems in the area, which has already lost over half of its natural vegetation over the course of the past 20 years [30]. Legally, further land use change is possible, though the Brazilian Forest Code regulates the agricultural expansion by protecting $35 \%$ of native vegetation in private properties [30]. From the perspective of planetary boundaries, the loss of biodiversity is a high risk [43]. Literature (see e.g., [30]) further confirms the importance of the questions on the potential deterioration of water quality due to sugarcane butanol production processes. Thus, business operators should be aware of the effects of, for example, their pesticide and fertiliser loading [30]. When investigating whether land use change from pastureland to sugarcane cropland decreases or increases carbon stock in Cerrado, Mello et al. [53] concluded that the carbon stock is lower in Cerrado sugarcane cropland than pastureland or natural vegetation.

\section{The sustainability orientation and the approach for a sustainability-oriented bioenergy business}

In summary, bioenergy companies' conception of the quantity of components of the bioenergy system expands as their maturity of corporate responsibility for sustainability develops. In the sustainability orientation, the sustainability challenges of the whole bioenergy system, both the bioenergy production chain and the operational environment, are studied in parallel. The following list provides a high-level overview of the extent of systemic thinking that the bioenergy operators need to possess, and the systemic components that the bioenergy operators need to explore to be able to operate at the most mature level of corporate responsibility of sustainability. The components may interact through direct and indirect material and energy inputs and outputs, monetary flows, and information exchange and human capital flows, of which the indirect flows would require system expansion:

- Identification of life cycle stages and operators and description of the unit processes;

- Description of the operational environment at each life cycle stage;

- Acquisition of a general understanding of the planetary boundaries and human needs;

- Identification of the factors in the operational environment that have the potential to contribute to global sustainable development in the areas of the planetary boundaries;

- Identification of how the bioenergy system (operators and processes) contributes to the factors in the operational environment that have the potential to contribute to the global sustainable development in the areas of the planetary boundaries;

- Identification of the challenges and opportunities inherent in the ecosystem and society conditions in the operational environment that contribute to fulfilling local human needs; 
- Identification of how the bioenergy system (operators and processes) contributes to the challenges and opportunities that arise within the ecosystem and society conditions the operational environment that contribute to fulfilling local human needs;

- Identification of stakeholders, their requirements and expectations;

- Identification of the impacts bioenergy processes or the conduct of bioenergy operators have on different stakeholders, identified, for example, through indicators;

- Identification of the impacts different stakeholders have on the bioenergy processes or the conduct of bioenergy operators.

Formulating the contributions to sustainability that are outlined above in the form of questions could help bioenergy operators to identify sustainability issues because asking questions might be easier than forming statements. The questions might further encourage operators to identify solutions and the information required to identify the sustainable answer. Finding suitable methods and tools to answer the sustainability questions is important. Questions about the factors that contribute to planetary boundaries or human needs could require the collection of background information, for example, indicator values, and the questions about the opportunities for bioenergy services to contribute to these questions could require deeper analysis, knowledge and wisdom to answer. As discussed in the workshops, the bioenergy systems should operate in symbiosis with the operational environment.

The following examples represent information about the Brazilian contribution to planetary boundaries in the context of the case study. A factor that contributes to the global sustainable development in the subject areas of the planetary boundaries, namely climate change and biodiversity, is land use change. Land use change in tropical forests can release significant amounts of carbon dioxide into the atmosphere, thus influencing the climate [54]. Between 2005 and 2009, Brazil, however, decreased the deforestation of the Amazon rainforest by $36 \%$ of its historical levels [54] and $70 \%$ during the past decade [55]. The Cerrado area is classified as one of the most threatened ecosystems in the world [30]. The area has lost over half of its natural vegetation over the course of the past 20 years [30]. Agricultural expansion, in particular, poses a significant threat to the area and its biodiversity [30].

Furthermore, the challenges and opportunities that are inherent in the ecosystems and the social conditions that impact the fulfilment of human needs in the Brazilian operational environment can be identified. The UN has estimated that the population will grow from 195 million in 2010 to 231 million in 2050 [56]. The Brazilian constitutional right to electricity cannot be guaranteed [57]. The rural electrification program aims to improve access to electricity in the rural areas [58]. Furthermore, the risk of power failures is relatively high at $20 \%$ [56]. The failures occur among various social groups, as well as industries, for different reasons [57]. On hot summer days, the energy consumption of cooling devices sharply increases electricity consumption [59]. Bioenergy operators could, thus, consider whether they are able to contribute to increasing the reliability of the distribution of electricity. As a factor that influences quality of life, child labour has decreased in Brazil [60]. The majority of child labour that is in use in Brazil is employed agriculture [60]. Because children do not need to do adults' work, i.e. child labour should be avoided, the biofuel producer needs to be aware of the risk of contributing to an increase in child labour and the opportunity to decrease child labour.

As providers of ecosystem services, bioenergy systems are in an interesting position as a link between the environmental boundaries and human needs [6]. The fulfilment of human needs, and consequently the well-being of humans, depends on ecosystem services [61]. Thus, the purpose of a bioenergy product, service and business can be 
founded on fulfilling the basic human need for a tolerable living temperature, and fulfilling additional human needs through electricity and mobility. In modern societies, electricity, heating, cooling and transportation are standard services. Thus, the extent to which businesses can demonstrate maturity in corporate responsibility for sustainability through the creative provision of such services could be somewhat limited. Businesses that operate at a higher maturity level of corporate responsibility for sustainability should, however, recognise that bioenergy systems may also add value to local communities by simultaneously fulfilling higher human needs; for example, needs for activity and participation [49].

Gasparatos et al. [7] stated that, although biofuels provide ecosystem services, they also compromise other ecosystem services. A commonly cited example is that of food. These trade-offs between ecosystem services are relevant in the assessment of the sustainability of bioenergy systems because the principle of sustainable development assumes that bioenergy operations should not deprive current and future generations of the possibility to fulfil their needs [62]. Another interesting question for mature bioenergy business could be the justification of bioenergy in the energy mix in comparison to other renewable or non-renewable energy forms since alternative energy options could similarly compromise ecosystem services.

The above-listed approach suggests the inclusion of stakeholder requirements and expectations at the level of sustainability orientation, although literature also examines the contrary scenario. Sustainability can be considered a normative concept [63], which would advocate for the inclusion of a normative element in the approach. Furthermore, Arias-Maldonado [37] discussed how the concept of open sustainability comprises several subjective conceptions of sustainability that require democratic and open communications. Buchholz et al. [9] suggested a failure of bioenergy systems in the case of the deficient participation of stakeholders. Arias-Maldonado [37] compared closed sustainability with strong sustainability with regard to, for example, the nonsubstitutability of natural capital and the insistence on systemic transformation. Thus, a slight controversy to the ideology of strong sustainability exists in the inclusion of stakeholder requirements. However, as discussed above, the sustainability orientation could possibly be characterised as a specific area of the profitability-acceptability orientation. In such a case the broad inclusion of stakeholders and their non-stated expectations is crucial within the approach. The identification of sustainability challenges and opportunities in the Brazilian context could help bioenergy business operators to formulate their value propositions [64], which is also related to the ideology of value creation.

The sustainability questions at the more mature levels of corporate responsibility for sustainability had a system expansion perspective, i.e., the indirect consequences of measures directly linked to the bioenergy operations were considered. For example, "Does sugarcane cultivation force other land uses into more highly biodiverse land areas?". The questions reached an ethical level, and included considerations of the acceptability of biofuel use in road transportation and its possible rebound effects (favouring cars due to the green image of biofuels) as well as the acceptability of biobutanol due to toxicity-induced health effects during production, for example.

The tools or methods that could be employed at the highest maturity level remained quite vague, and the discussion primarily concerned extensive sustainability issues. A combination of several different methods and tools from the other maturity levels would be necessary. Applying system analytical perspectives to the sustainability of the bioenergy system should serve as a starting point, and parts of the bioenergy system could be studied using a variety of methods to produce, for example, indicators.

Considering the sustainability questions especially in their own well-defined core processes might be of primary interest for bioenergy operators. However, at different 
stages of the bioenergy chain, the extent of sustainability impacts and the power to change the impacts varies from operator to operator. The question remains; In practice, who is responsible for the sustainability of the bioenergy chain. Is it sufficient for the bioenergy operators to try to improve the state of the sustainability of their own core processes? Do small improvements make a difference in the context of the whole system? Or should operators define and concentrate on the major leverage points [9] of the whole system?

Sustainability improvements require interactions between the various operators that exist in the supply chain and these have yet to be examined in detail. Furthermore, the roles of different operators and differences in their relevant local sustainability questions could be of interest.

The workshop discussions motivated the question as to whether sustainability could be seen as a source of competitive advantage for businesses or whether true sustainability requires tighter cooperation between competing companies to solve shared sustainability challenges and problems. In that case, businesses with mature responsibility for sustainability would seek cooperation with competitors, which blurs the concept of business, capitalism, and competition. However, as biofuel business operators with a conventional profitability or acceptability orientation to sustainability would use, for example, their verified improvements in efficiency in their competition against rivals, a sustainability-oriented business operator could use knowledge about the extent to which the bioenergy business compromises human and planetary systems less than alternative services.

\section{CONCLUSIONS}

This study characterised the maturity levels of corporate responsibility for sustainability in the local bioenergy system context with regard to the types of questions and the types of tools and methods applicable at each level. The proposed maturity model seems suitable for the bioenergy business when a number of factors are taken into account. The maturity levels have a profitability and an acceptability orientation. These orientations tend to converge as a bioenergy operator's sustainability strategies and activities mature, until the point at which the perspective shifts from business- and product-based sustainability management to the perspective of sustainability orientation and sustainability based business and product management. Through this process the conception of sustainability shifts from weak to strong sustainability. Different levels of the maturity of corporate responsibility for sustainability might be emphasised at different stages of product maturity.

The shift from profitability-acceptability to sustainability orientation, and the types of sustainability questions, the answers to these questions and the applicable methods at the level of the mature sustainability orientation require more research. The sustainability orientation could possibly be characterised as a specific area of the profitabilityacceptability orientation. However, the research shows that bioenergy companies should develop their ability to enhance holistic and systemic thinking that incorporates the planetary boundaries, local environmental boundaries and social foundation together with the bioenergy processes. Bioenergy production could be justified if it contributes to the process by which the urgent environmental and human challenges in the local and global level can be addressed. The bioenergy business has the inherent sustainability advantage that it provides the ecosystem services that are vital for the fulfilment of basic human needs. However, consideration of sustainability in the local context of the bioenergy system presents numerous opportunities for bioenergy operators to reconsider their level of maturity of responsibility for sustainability. The shift from sustainability-as-usual to sustainability excellence does not exclude the need for bioenergy companies to consider the basic aspects of sustainability. The shift in perspective, however, raises more 
extensive sustainability questions that require a combination of various methods to manage.

The advantages of a more mature approach to corporate responsibility for sustainability include a broader spatial and temporal view of sustainability challenges and opportunities. As the bioenergy business strives for symbiosis with the micro-, meso- and macro-level operational environment, it establishes a firmer and indisputable foundation for business continuity in the long term.

\section{ACKNOWLEDGEMENT}

This work was carried out in the Sustainable Bioenergy Solutions for Tomorrow (BEST) research program coordinated by FIBIC Ltd. and CLEEN Ltd. with funding from the Finnish Funding Agency for Innovation, Tekes. The authors would like to thank Sari Silventoinen for language advice and the editor and reviewer from the $10^{\text {th }}$ Conference on Sustainable Development of Energy, Water and Environment Systems (SDEWES) for valuable comments that helped to improve the first version of this paper, which was published at the SDEWES Conference Proceedings in 2015. Furthermore, the authors would like to acknowledge the editor and the three reviewers of the Journal of Sustainable Development of Energy, Water and Environment Systems and the language editor for their helpful comments that guided the process by which this paper was rewritten for journal publication.

\section{REFERENCES}

1. International Energy Agency (IEA), 2015 Key World Energy Statistics, http://www.iea.org/publications/freepublications/publication/KeyWorld_Statistics_201 5.pdf, [Accessed: 13-May-2016]

2. Eurostat, Energy - Main Tables, http://ec.europa.eu/eurostat/web/energy/data/maintables, [Accessed: 06-October-2016]

3. Rimppi, H., Uusitalo, V., Väisänen, S. and Soukka, R., Sustainability Criteria and Indicators of Bioenergy Systems from Steering, Research and Finnish Bioenergy Business Operators' Perspectives, Ecol. Indic., Vol. 66, pp 357-368, 2016, https://doi.org/10.1016/j.ecolind.2016.02.005

4. Cherubini, F. and Strømman, A. H., Life Cycle Assessment of Bioenergy Systems: State of the Art and Future Challenges, Biores. Tech., Vol. 102, No. 2, pp 437-451, 2011, https://doi.org/10.1016/j.biortech.2010.08.010

5. Sheehan, J. J., Biofuels and the Conundrum of Sustainability, Curr. Opin. Biotechnol., Vol. 20, No. 3, pp 255-380, 2009, https://doi.org/10.1016/j.copbio.2009.05.010

6. The Finnish Association for Nature Conservation, Ecosystem Services (in Finnish), http://www.sll.fi/mita-me-teemme/ekosysteemipalvelut, [Accessed: 07-April-2015]

7. Gasparatos, A., Stromberg, P. and Takeuchi, K., Biofuels, Ecosystem Services and Human Wellbeing: Putting Biofuels in the Ecosystem Services Narrative, Agric. Ecosyst. Environ., Vol. 142, No. 3-4, pp 111-128, 2011, https://doi.org/10.1016/j.agee.2011.04.020

8. Dias, M. A. P., Haddad Alves, A. S. and Vianna, J. N. S., A Pathway to Energy and Food Security with Biodiesel, J. Sustain. Dev. Energy Water Environ. Syst., Vol. 4, No. 3, pp 242-261, 2016, https://doi.org/10.13044/j.sdewes.2016.04.0020

9. Buchholz, T. S., Volk, T. A. and Luzadis, V. A., A Participatory Systems approach to modeling Social, Economic, and Ecological Components of Bioenergy, Energy Policy, Vol. 35, No. 12, pp 6084-6094, 2007, https://doi.org/10.1016/j.enpol.2007.08.020

10.Niemistö, J., Saavalainen, P., Pongrácz, E. and Keiski, R. L., Biobutanol as a Potential Sustainable Biofuel - Assessment of Lignocellulosic and Waste-based Feedstocks, J. Sustain. Dev. Energy Water Environ. Syst., Vol. 1, No. 2, pp 58-77, 2013, https://doi.org/10.13044/j.sdewes.2013.01.0005 
11.Kettl, K.-H., Niemetz, N., Eder, M. and Narodoslawsky, M., Optimal Renewable Energy Systems for Regions, J. Sustain. Dev. Energy Water Environ. Syst., Vol. 2, No. 1, pp 88-99, 2014, https://doi.org/10.13044/j.sdewes.2014.02.0008

12.Dyllick, T. and Hockerts, K., Beyond the Business Case for Corporate Sustainability, Bus. Strategy Environ., Vol. 11, No. 2, pp 130-141, 2002, https://doi.org/10.1002/bse.323

13.Ketola, T., Five Leaps to Corporate Sustainability through a Corporate Responsibility Portfolio Matrix, Corp. Soc. Responsib. Environ. Manag., Vol. 17, No. 6, pp 320-336, 2010, https://doi.org/10.1002/csr.219

14.Baumgartner, R. J. and Ebner, D., Corporate Sustainability Strategies: Sustainability Profiles and Maturity Levels, Sustain. Dev., Vol. 18, No. 2, pp 76-89, 2010, https://doi.org/10.1002/sd.447

15.Dyllick, T. and Muff, K., Clarifying the Meaning of Sustainable Business: Introducing a Typology From Business-as-Usual to True Business Sustainability, Organ. Environ., Vol. 29, No. 2, pp 156-174, 2016, https://doi.org/10.1177/1086026615575176

16.Whiteman, G., Walker, B. and Perego, P., Planetary Boundaries: Ecological Foundations for Corporate Sustainability, J. Manag. Stud., Vol. 50, No. 2, pp 307-336, 2013, https://doi.org/10.1111/j.1467-6486.2012.01073.x

17.Kurka, T. and Blackwood, D., Participatory Selection of Sustainability Criteria and Indicators for Bioenergy Developments, Renew. Sustain. Energy Rev., Vol. 24, pp 92-102, 2013, https://doi.org/10.1016/j.rser.2013.03.062

18.Schumpeter, A New Green Wave, http://www.economist.com/news/business/21614152few-pioneering-businesses-are-developing-sustainability-policies-worthy-name-new, [Accessed: 05-August-2015]

19.Henkel, Strategy, http://www.henkel.com/sustainability/strategy, [Accessed: 20-May2015]

20.Dittrich-Krämer, B., From LCA to Eco-Efficiency to SEEBALANCE ${ }^{\circledR}$, http://www.peinternational.com/uploads/media/11_BASF_Dittrich-Kr\%C3\%A4mer.pdf, [Accessed: 07-May-2015]

21.SFS-EN-ISO 14040, Environmental Management, Life Cycle Assessment, Principles and Framework, Finnish Standards Association SFS, Helsinki, Finland, 2006.

22.Dreyer, L. C., Hauschild, M. Z. and Schierbeck, J., A Framework for Social Life Cycle Impact Assessment, Int. J. LCA, Vol. 11, No. 2, pp 88-97, 2006, https://doi.org/10.1065/lca2005.08.223

23.Klöppfer, W. and Ciroth, A., Is LCC Relevant in a Sustainability Assessment?, Int. J. LCA, Vol. 16, No. 2, pp 99-101, 2011, https://doi.org/10.1007/s11367-011-0249-y

24.Klöppfer, W. and Grahl, B., Life Cycle Assessment (LCA) - A Guide to Best Practice, Wiley, 2014, https://doi.org/10.1002/9783527655625

25.Wu, M., Wang, M., Liu, J. and Huo, H., Life-Cycle Assessment of Corn-Based Butanol as a Potential Transportation Fuel, Argonne National Laboratory, Energy Systems Division, Report ANL/ESD/07-10, 2007.

26.Mariano, A. P., Dias, M. O. S., Junqueira, T. L., Cunha, M. P., Bonomi, A. and Filho, R. M., Butanol Production in a First-generation Brazilian Sugarcane Biorefinery: Technical Aspects and Economics of Greenfield Projects, Bioresour. Technol., Vol. 135, pp 316-323, 2013, https://doi.org/10.1016/j.biortech.2012.09.109

27.Swana, J., Yang, Y., Behnam, M. and Thompson, R., An Analysis of Net Energy Production and Feedstock availability for Biobutanol and Bioethanol, Bioresour. Technol., Vol. 102, No. 2, pp 2112-2117, 2011, https://doi.org/10.1016/j.biortech.2010.08.051

28.Efe, C., Straathof, A. J. J. and van der Wielen, L. A. M., Technical and Economical Feasibility of Production of Ethanol from Sugar Cane and Sugar Cane Bagasse, B-Basic Internal Report, Delft University of Technology, Delft, The Netherlands, 2005. 
29.Ajanovic, A. and Haas, R., On the Future Prospects and Limits of Biofuels in Brazil, the US and EU, Applied Energy, Vol. 135, pp 730-737, 2014, https://doi.org/10.1016/j.apenergy.2014.07.001

30.Filoso, S., Braga do Carmo, J., Mardegan, S. F., Machado Lins, S. R., Figueiredo Gomes, T. and Martinelli, L. A., Reassessing the Environmental Impacts of Sugarcane Ethanol Production in Brazil to help meet Sustainability Goals, Renew. Sustain. Energy Rev., Vol. 52, pp 1847-1856, 2015, https://doi.org/10.1016/j.rser.2015.08.012

31.Porter, M. E., Competitive Strategy: Techniques for Analyzing Industries and Competitors, The Free Press, USA, 1980.

32.Ansoff, H. I., Implanting Strategic Management, Prentice/Hall International, USA, 1984. 33.Linnanen, L., Boström, T. and Miettinen, P., Environmental Management: Life Cycle Thinking in Corporate Actions (in Finnish), Weilin + Göös, Juva, 1994.

34.Ketola, T., Responsible Business - From Words to Deeds (in Finnish), Edita Prima Oy, Helsinki, Finland, 2005.

35.Heikkurinen, P., Reframing Strategic Corporate Responsibility: From Economic Instrumentalism and Stakeholder Thinking to Awareness and Sustainable development, Ph.D. Thesis, Aalto University School of Business, Department of Management and International Business, Corporate Responsibility Research Group, Helsinki, Finland, 2013.

36.Lintukangas, K., Kähkönen, A.-K. and Ritala, P., Supply Risks as Drivers of Green Supply Management Adoption, J. Clean. Prod., Vol. 112, Part 3, pp 1901-1909, 2016, https://doi.org/10.1016/j.jclepro.2014.10.089

37.Arias-Maldonado, M., Rethinking Sustainability in the Anthropocene, Environ. Politics, Vol. 22, No. 3, pp 428-446, 2013, https://doi.org/10.1080/09644016.2013.765161

38.Fava, J., The Sustainability Maturity Curve, http://www.thinkstep.com/blog/blogsustainability-maturity-curve, [Accessed: 20-May-2015]

39.Papagiannakis, G., Voudouris, I. and Lioukas, S., The Road to Sustainability: Exploring the Process of Corporate Environmental Strategy Over Time, Bus. Strategy Environ., Vol. 23, No. 4, pp 254-271, 2014, https://doi.org/10.1002/bse.1781

40.Heink, U. and Kowarik, I., What are Indicators? On the definition of Indicators in Ecology and Environmental Planning, Ecol. Indic., Vol. 10, No. 3, pp 584-593, 2010, https://doi.org/10.1016/j.ecolind.2009.09.009

41.Buysse, K. and Verbeke, A., Proactive Environmental Strategies: A Stakeholder Management Perspective, Strateg. Manag. J., Vol. 24, No. 5, pp 453-470, 2003, https://doi.org/10.1002/smj.299

42.Ketola, T., Pre-Morphean Paradigm - An Alternative to Modern and Post-modern Paradigms of Corporate Sustainability, Sustain. Dev., Vol. 17, No. 2, pp 114-126, 2009 , https://doi.org/10.1002/sd.406

43.Rockström, J., Steffen, W., Noone, K., Persson, Å., Chapin, F. S., Lambin, E. F., Lenton, T. M., Scheffer, M., Folke, C., Schellnhuber, H. J., Nykvist, B., de Wit, C. A., Hughes, T., van der Leeuw, S., Rodhe, H., Sörlin, S., Snyder, P. K., Costanza, R., Svedin, U., Falkenmark, M., Karlberg, L., Corell, R. W., Fabry, V. J., Hansen, J., Walker, B., Livermen, D., Richardson, K., Crutzen, P. and Foley J. A., A Safe Operating Space for Humanity, Nature, Vol. 461, pp 472-475, 2009, https://doi.org/10.1038/461472a

44.Steffen, W., Richardson, K., Rockström, J., Cornell, S. E., Fetzer, I., Bennett, E. M., Biggs, R., Carpenter, S. R., de Vries, W., de Wit, C. A., Folke, C., Gerten, D., Heinke, J., Mace, G. M., Persson, L. M., Ramanathan, V., Reyers, B. and Sörlin, S., Planetary Boundaries: Guiding Human development on a changing Planet, Science, Vol. 347, No. 6223, 2015, https://doi.org/10.1126/science.1259855

45.Raworth, K., A Safe and Just Space for Humanity: Can we Live within the Doughnut?, http://www.oxfam.org/sites/www.oxfam.org/files/dp-a-safe-and-just-space-forhumanity-130212-en.pdf, [Accessed: 24-October-2014] 
46.Finnveden, G., Hauschild, M. Z., Ekvall, T., Guinée, J., Heijungs, R., Hellweg, S., Koehler, A., Pennington, D. and Suh, S., Recent developments in Life Cycle Assessment, J. Env. Manag., Vol. 91, No. 1, pp 1-21, 2009, https://doi.org/10.1016/j.jenvman.2009.06.018

47.Hayashi, T., van Ierland, E. C. and Zhu, X., A Holistic Sustainability assessment Tool for Bioenergy using the Global Bioenergy Partnership (GBEP) Sustainability Indicators, Biomass Bioenergy, Vol. 66, pp 70-80, 2014, https://doi.org/10.1016/j.biombioe.2014.01.040

48.Räsänen, J., The disappearing Trick of Textile Waste: The Possibilities for Design for End-of-life in Finnish Textiles and Clothing Production (in Finnish), M.Sc. Thesis, University of Lapland, Rovaniemi, Finland, 2011.

49.Schultz, L. and Tapio, P., The Sufficiency Strategy of Consumption in the Light of need Theories (in Finnish), Alue ja Ympäristö, Vol. 40, No. 1, pp 3-16, 2011.

50.Kamensky, M., Strategic Management: Diamond of Success (in Finnish), Talentum, Helsinki, Finland, 2014.

51.Machado, P. G., Araujo Picoli, M. C., Torres, L. J., Garcia Oliveira, J. and Walter, A., The use of Socioeconomic Indicators to assess the Impacts of Sugarcane Production in Brazil, Renew. Sustain. Energy Rev., Vol. 52, pp 1519-1526, 2015, https://doi.org/10.1016/j.rser.2015.07.127

52.Herreras Martínez, S., van Eijck, J., Pereira da Cunha, M., Guilhoto, J. J. M., Walter, A. and Faaij, A., Analysis of Socio-economic Impacts of Sustainable Sugarcane-ethanol production by means of Inter-regional Input-output Analysis: Demonstrated for Northeast Brazil, Renew. Sustain. Energy Rev., Vol. 28, pp 290-316, 2013, https://doi.org/10.1016/j.rser.2013.07.050

53.Mello, F. F. C., Cerri, C. E. P., Davies, C. A., Holbrook, N. M., Paustian, K., Maia, S. M. F., et al., Payback Time for Soil Carbon and Sugar-cane Ethanol, Nat. Clim. Chang., Vol. 4, pp 605-609, 2014, https://doi.org/10.1038/nclimate2239

54.Nepstad, D., Soares-Filho, B. S., Merry, F., Lima, A., Moutinho, P., Carter, J., Bowman, M., Cattaneo, A., Rodrigues, H., Schwartzman, S., McGrath, D. G., Stickler, C. M., Lubowski, R., Piris-Cabezas, P., Rivero, S., Alencar, A., Almeida, O. and Stella, O., The end of Deforestation in the Brazilian Amazon, Science, Vol. 326, No. 5958, pp 1350-1251, 2009, https://doi.org/10.1126/science.1182108

55.Nepstad, D., McGrath, D., Stickler, C., Alencar, A., Azevedo, A., Swette, B., Bezerra, T., DiGiano, M., Shimada, J., Seroa da Motta, R., Armijo, E., Castello, L., Brando, P., Hansen, M. C., McGrath-Horn, M., Carvalho, O. and Hess, L., Slowing Amazon deforestation through Public Policy and Interventions in Beef and Soy Supply Chain, Science, Vol. 344, No. 6188, pp 1118-1123, 2014, https://doi.org/10.1126/science.1248525

56.UN, United Nations Department of Economic and Social Affairs, Demographic Components of Future Population Growth, http://www.un.org/en/development/desa/population/publications/pdf/technical/TP20133.pdf, [Accessed: 14-April-2015]

57.Rocha Leal da Paz, L., Fidelis da Silva, N. and Pinguelli Rosa, L., The Paradigm of Sustainability in the Brazilian Energy Sector, Renew. Sustain. Energy Rev., Vol. 11, No. 7, pp 1558-1570, 2007, https://doi.org/10.1016/j.rser.2005.12.005

58.Gómez, M. F., Sanches-Pereira, A. and Silveira, S., Technology for Social Inclusion: The Case of Electricity Access in the Brazilian Amazon, J. Sustain. Dev. Energy Water Environ. Syst., Vol. 1, No. 3, pp 237-259, 2013, https://doi.org/10.13044/j.sdewes.2013.01.0018 People, Blackouts in Brazil, http://www.economist.com/blogs/americasview/2014/02/blackouts-brazil, [Accessed: 14-April-2015] 
60.Rosati, F. C., Manacorda, M., Kovrova, I., Koseleci, N. and Lyon, S., Understanding the Brazilian Success in Reducing Child Labour: Empirical Evidence and Policy Lessons, http://www.ucw-project.org/attachment/Brazil_20june1120110622_103357.pdf, [Accessed: 13-April-2015]

61.Griggs, D., Stafford-Smith, M., Gaffney, O., Rockström, J., Öhman, M. C., Shyamsundar, P., Steffen, W., Glaser, G., Kanie, N. and Noble, I., Sustainable Development Goals for People and Planet, Nature, Vol. 495, pp 305-307, 2013, https://doi.org/10.1038/495305a

62.WCED, Our Common Future, United Nations World Commission on Environment and Development, The Brundtland Report, 1987.

63.Rametsteiner, E., Pülzl, H., Alkan-Olsson, J. and Frederiksen, P., Sustainability Indicator development - Science or Political Negotiation?, Ecol. Indic., Vol. 11, No. 1, pp 61-70, 2011, https://doi.org/10.1016/j.ecolind.2009.06.009

64.Richter, M., Utilities' Business Models for Renewable Energy: A Review, Renew. Sustain. Energy Rev., Vol. 16, No. 5, pp 2483-2493, 2012, https://doi.org/10.1016/j.rser.2012.01.072 
The appendix divides the local sustainability questions according to the corresponding levels in the model of the maturity of corporate responsibility for sustainability. The profitability orientation has two levels: economic feasibility studies and efficiency measures, the acceptability orientation has two levels: compliance with legislative requirements and responding to enquiries from stakeholders, the profitabilityacceptability orientation has one level: creating value to multiple stakeholders and the sustainability orientation has one level: responding to urgent planetary and human sustainability challenges or opportunities through bioenergy solutions.

\section{THE PROFITABILITY ORIENTATION}

\section{Economic feasibility studies}

The following list presents examples of the local sustainability questions related to economic feasibility studies per life cycle stage of biobutanol that were discussed in Workshop 2.

Cultivation of sugarcane:

- Does the RED contain such conditions for the renewal rate of raw material that they could benefit the economic feasibility of operations?

- How does local legislation affect the economic feasibility of operations?

- Are such investments subsidised?

- Is there infrastructure, such as roads, in the area?

Processing of sugarcane and biobutanol:

- Is it feasible for the refinery to use sugarcane as a raw material of biobutanol?

- What is the necessary amount of subsidies for investment?

Delivery and storage of biobutanol:

- How do the requirements related to importing butanol into the EU area affect economic feasibility?

- Could biobutanol production increase an oil company's profits?

- Are economic subsidies available for investments in the biobutanol distribution network?

Use of biobutanol as transportation fuel:

- How do the current (10\% by 2020) and future (max. 5\% produced from food crops) requirements of the RED affect economic feasibility?

- How do the RED requirements on greenhouse gas emission reduction affect economic feasibility?

- How does the development of fuel taxation affect the economic feasibility of biobutanol?

- How do subsidies affect the selection of the process/technology or end-product?

- How much does the end-product need to be subsidised before its production is economically feasible?

Sustainability questions originating purely from business economic efficiency objectives and footprint reduction objectives that lead to win-win situations for the business economy and different stakeholders were difficult to distinguish. Therefore, they are considered collectively below in "The profitability-acceptability orientation".

\section{THE ACCEPTABILITY ORIENTATION}

\section{Compliance with legislative requirements}

The following list presents examples of local sustainability questions related to legislative requirements per life cycle stage of biobutanol that were discussed in Workshop 2. 
Cultivation of sugarcane:

- Does sugarcane comply with the sustainability criteria?

- Does land use change decrease or increase carbon stock?

- Does the RED contain conditions for the renewal rate of raw material that they could benefit the economic feasibility of operations?

- Does the RED contain a default value for butanol?

- How would an indirect land use change coefficient affect the greenhouse gas calculation of the $1^{\text {st }}$ generation biofuels according to the RED?

- How does local legislation affect the economic feasibility of operations?

- Do losses of carbon stock occur as a result of the utilisation of new production areas?

- Do the operations decrease the quality of local water resources?

- Do the operations decrease the quality of the soil that is available for agriculture?

- Does the necessary transportation infrastructure decrease air quality?

- Does biodiversity decrease due to sugarcane cultivation?

- Do fertilisers and pesticides decrease environmental quality, e.g., by causing eutrophication or toxicity impacts?

- What greenhouse gas emissions result from land use change?

- How can information for greenhouse gas calculations be collected from the whole chain?

- Are the local authorities authorised to lease the land?

- Are human rights respected in the harvesting chain?

- Does chemical use cause health impacts?

Processing of sugarcane and biobutanol:

- Is the best available technology utilised in production?

- What air emissions does the process generate?

- Do the operations deteriorate local air quality?

- Does the increasing transportation deteriorate air quality?

- Which water emissions does the process generate?

- Do the operations deteriorate local water quality?

- Which soil emissions does the process generate?

- Do the operations deteriorate the quality of soil suitable for agriculture?

- Can emissions be prevented?

- Has occupational safety been taken into account?

Delivery and storage of biobutanol:

- How do requirements related to the importation of butanol to the EU area affect economic feasibility?

- What emissions does transportation cause?

- Can emissions be prevented?

- Do distribution points deteriorate local air quality?

- Do distribution points or storage put local water resources at risk?

- Does the distribution network include operations that are hazardous to health?

- Can the toxic butanol be delivered safely?

- How can butanol leakages during transportation be prevented?

- Is butanol explosive?

- Are there occupational safety risks due to leakages or accidents?

- Does the distribution network incur a risk of fire or explosion?

Use of biobutanol as transportation fuel: 
- Does the use of biobutanol decrease greenhouse gas emissions in comparison to the use of fossil fuels?

- What are the restrictions of the EU ILUC Directive for 1st generation biofuels?

- How do the current (10\% by 2020) and future (max. 5\% produced from food crops) requirements of the RED affect economic feasibility?

- How do the RED requirements on greenhouse gas emission reduction affect economic feasibility?

- What kind of positive impacts do EU sustainability criteria have on the production chain?

- Is the EU planning distribution targets of biofuels for 2020 ?

- Can separate legislation be expected for food-based and new generation raw materials or fuels derived from them?

- Does the use generate heavy metal emissions?

- Does the use generate emissions of particulates?

- What kind of problems do emissions from transport cause?

- Does biobutanol increase emissions in proximity to the use?

- How does the toxicity of butanol leakages impact the environment and where do the leakages transport?

- Do fuel distribution stations cause risks for ground water?

- Do fuel distribution stations or the use of the fuel cause emissions that are hazardous to health?

- Does the use of biobutanol as a transport fuel incur a risk of fire or explosion?

\section{Responding to enquiries from stakeholders}

The following list presents examples of local sustainability questions related to stakeholder enquiries and requirements per life cycle stage of biobutanol that were discussed in Workshop 2.

Cultivation of sugarcane:

- What kind of standardisation systems exist for sugarcane?

- Can raw material production be certified?

- Does certification help to develop sustainability at the first stages of the biofuel chain?

- Does the production process include stages that are hazardous for health?

- Has the safety of harvesting and cultivation been taken care of?

- Does the work include risks of accidents?

- Are there occupational health risks related to ergonomics?

- Does local fauna cause occupational health risks?

- What kind of contracts of employment do farmers have and with whom?

- Have the rights of indigenous people been taken into account?

- Is ethical use of labour force ensured?

- Is child labour utilised?

- Is the livelihood of local people secured?

- Does chemical use cause health impacts?

- Does the work include mental risks?

- What kind of problems do hot working conditions cause?

- Is it feasible from local residents' perspective to use sugarcane for biobutanol production?

- Does the sugarcane production influence the livelihood of local residents?

Processing of sugarcane and biobutanol:

- Are there standards and are operations in accordance with them? 
- Has occupational safety been taken into account?

- Does the production process include stages that are hazardous for health?

- Does the production process include stages that are hazardous?

- What kind of occupational safety challenges does the toxicity of butanol cause?

- Is more research on social impacts necessary?

- What is the local opinion of a large production plant?

Delivery and storage of biobutanol:

- Is the fuel certifiable?

- How can butanol leakages during transportation be prevented?

- Are there occupational safety risks due to leakages or accidents?

- Does the construction or use of the distribution network include hazardous stages? Use of biobutanol as transportation fuel:

- Is the EU planning distribution targets of biofuels for 2020?

- Can separate legislation be expected for food-based and new generation raw materials or fuels derived from them?

- Does the use generate heavy metal emissions?

- Does the use generate emissions of particulates?

- Does the use cause risk of fire or explosion?

- What problems could occur at fuel distribution stations and are they avoidable?

\section{THE PROFITABILITY-ACCEPTABILITY ORIENTATION}

\section{Efficiency measures to cut costs and to protect the environmental or human systems}

Sustainability questions originating purely from business economic efficiency objectives and footprint reduction objectives that lead to win-win situations for the business economy and different stakeholders were difficult to distinguish. Therefore, they are considered collectively in this section. The following list presents examples of local sustainability questions related to efficiency measures and footprint reduction per life cycle stage of biobutanol that were discussed in Workshop 2.

Cultivation of sugarcane:

- Does energy sugarcane cultivation compete with food production for land area?

- Is the utilisation of poorer quality sugar possible?

- Are there waste materials suitable for utilisation in the area?

- Are there by-products suitable for utilisation in the area?

- Are there alternative raw materials in the area?

- Are there seasonal variations in sugarcane yields and are they foreseeable and manageable?

- Can sugarcane yield per area be increased?

- Are phosphorus resources sufficient?

- Can energy production based on fossil fuels be decreased?

- Can surface or ground water use be decreased?

- Can chemical consumption be decreased?

- Can waste production be decreased?

- Can the efficiency of the process and equipment be increased?

- Can by-products be recycled?

- Which harvesting technology is used (manual or mechanical)?

- What is the water consumption of the process?

- Is crop rotation necessary?

- Can surface or ground water use be decreased?

- Is water temporally or spatially distributed? 
- Is irrigation necessary?

- Which water resources are used for irrigation?

- Can fertiliser use be decreased?

- Can pesticide use be decreased?

- Does increasing transport increase congestion?

- How much does transport increase accidents?

Processing of sugarcane and biobutanol:

- Can surface or ground water use be decreased?

- Can chemical consumption be decreased?

- The technology is not optimal yet; is additional development needed before utilising it?

- Can by-products be recycled?

- Can the acetone be refined into other products?

- What is the energy efficiency of the whole chain?

- Could the process be energy self-sufficient?

- Can the efficiency of the process and equipment be increased?

- Could heat be recovered?

- Can by-products be recycled?

- Does the process consume a large amount of water?

- Does the construction of housing for employees result in the consumption of natural resources?

- Does increasing transport increase congestion?

- How much does the transport increase accidents?

Delivery and storage of biobutanol:

- Is water consumed?

- How much land do delivery and storage require?

- Could delivery vehicles be utilised for transportation of other productive goods, e.g., on their way back from the coast?

- What is the most feasible method of transportation: pipelines or trucks and tankers?

- Is the implementation of logistics reasonable (economically and regarding emissions)?

Use of biobutanol as transportation fuel:

- How much gasoline needs to be blended with biobutanol before the fuel blend can be used in a gasoline engine? Does biobutanol use cause problems in engines?

- What is the real blend wall?

\section{Creating value for multiple stakeholders}

The following list presents examples of local sustainability questions related to value creation for stakeholders per life cycle stage of biobutanol that were discussed in Workshop 2.

Cultivation of sugarcane:

- Does energy sugarcane cultivation compete with food production for land area?

- Sugar is food; is sugarcane use for energy acceptable?

- Is the utilisation of poorer quality sugar possible?

- Do losses of carbon stock occur due to the utilisation of new production areas?

- Does the establishment of the sugarcane cultivation area decrease opportunities for local species to find food, water, roaming space, or shelter?

- Can ecological corridors increase biodiversity? 
- Do fertilisers and pesticides decrease environmental quality e.g. by causing eutrophication or toxicity impacts?

- Do pesticides cause problems and how toxic are they?

- Do the operations spoil the landscape?

- Could new infrastructure benefit the local community?

- Are the cattle farmers forced to move?

- Are all (potential) uses of the area known?

- What problems does the relocation of labour force cause?

- Is education available for farmers (literacy and numeracy)?

- Is the livelihood of local people secured?

- Does chemical use have health impacts?

- Does the work include mental risks?

- What kind of problems do hot working conditions cause?

- Is it feasible to use sugarcane for biobutanol production from local residents' perspective?

- Does the sugarcane production influence the livelihood of local residents?

- Does the sugarcane harvesting stage generate employment opportunities for local people?

- Are local people suitable for the work?

- Are housing, other infrastructure, and services available for employees and their families in the area or at a reasonable distance?

- Is the additional education of the employees necessary?

Processing of sugarcane and biobutanol:

- Can surplus electricity from the process be fed into the local electrical network?

- Can energy production based on fossil fuels be reduced?

- Are there more sustainable refining technologies that aim at the same end product and end use?

- Can the production technologies be developed to be more ecologically sustainable?

- Do the operations spoil the landscape?

- Do the operations create new jobs in the area?

- Are jobs part-time or full-time?

- Do the new jobs replace other jobs?

- Where is the labour force available?

- Do the employees have social security (health care, kindergartens, water, and food)?

- How does the new production plant affect prices?

- How many jobs are created?

- Does sugarcane production influence the livelihood of local residents?

- Are local people suitable for the work?

- Are housing, other infrastructure, and services available for employees and their families in the area or at a reasonable distance?

- Is the additional education of the employees necessary?

- How is the tax revenue to the state affected?

Delivery and storage of biobutanol:

- Could new business be developed around by-products?

- Are fossil fuels utilised in transportation?

- How can butanol leakages during transportation be prevented?

- What are the impacts of toxic leakages on the whole chain? 
- Does the distribution network spoil the landscape?

- What are the impacts on the development of the area?

- Are secondary jobs increased?

- Does the distribution network cause a risk of fire or explosion?

- How is the tax revenue to the state affected?

- How many jobs are created?

- What is the regional value added?

Use of biobutanol as a transportation fuel:

- What kind of positive impacts do EU sustainability criteria have on the production chain?

- What emissions affect the environment in proximity to the use?

- Does the use generate heavy metal emissions?

- Does the use generate emissions of particulates?

- What kind of problems do emissions from transport cause?

- How does the toxicity of butanol leakages impact the environment and where do the leakages transport?

- Is consumer use of biobutanol subsidised?

- How is the tax revenue to the state affected?

- How many jobs are created?

\section{THE SUSTAINABILITY ORIENTATION}

\section{Responding to urgent sustainability challenges through bioenergy solutions}

The following list presents examples of local sustainability questions related to sustainability excellence per life cycle stage of biobutanol that were discussed in Workshop 2.

Cultivation of sugarcane:

- Are there more sustainable alternative uses for sugarcane?

- Does sugarcane cultivation force other land uses into more highly biodiverse land areas?

- Does pasture move elsewhere causing biodiversity risks?

- Is biodiversity linked with pasture?

Processing of sugarcane and biobutanol:

- Can surplus electricity from the process be fed into the local electrical network?

- Is the ABE process a reasonable choice as it includes large amounts of acetone?

- Would ethanol production be a more feasible choice than butanol production?

- What is the yield of butanol in comparison to the yield of ethanol?

Delivery and storage of biobutanol:

- What are the challenges of green leakage from Brazil to Europe?

- Why not produce ethanol for the Brazil domestic market instead of butanol for the European market?

- Could new business be developed around by-products?

- Is this business reasonable in the first place, regarding the toxicity of the end product?

- What role does the exportation of butanol play in Brazil's economy?

Use of biobutanol as transportation fuel:

- How much does the use of biobutanol decrease the use of fossil energy resources?

- How much can biobutanol production be sustainably increased? 
- Does the availability of biobutanol increase the popularity of cars and road transportation and their negative impacts if biobutanol has an ecological ("green") image?

- Is food as raw material problematic?

- What are the benefits of a higher calorific value?

- Does biobutanol have other uses?

- Why not use electric cars?

- How much energy is used during the life cycle in relation to the energy content of the end-product? 